OECDpublishing

\title{
LEVELLING THE \\ PLAYING FIELD
}

DISSECTING THE GENDER GAP IN THE FUNDING OF START-UPS

OECD SCIENCE, TECHNOLOGY AND INDUSTRY POLICY PAPERS June 2019 No. 73 
This paper was approved and declassified by oral procedure by the Committee on Industry, Innovation and Entrepreneurship (CIIE) on 8 April 2019 and prepared for publication by the OECD Secretariat.

The paper was prepared by Julie Lassébie (OECD/STI), Sahra Sakha (OECD/ECO), Tomasz Kozluk (OECD/ECO), Carlo Menon (Laterite), Stefano Breschi (Bocconi University) and Nick Johnstone (IEA).

Note to Delegations:

This document is also available on O.N.E under the reference code:

DSTI/CIIE(2019)3/FINAL

This paper is published under the responsibility of the Secretary-General of the OECD. The opinions expressed and the arguments employed herein do not necessarily reflect the official views of OECD member countries.

This document, as well as any data and any map included herein, are without prejudice to the status of or sovereignty over any territory, to the delimitation of international frontiers and boundaries and to the name of any territory, city or area.

The statistical data for Israel are supplied by and under the responsibility of the relevant Israeli authorities. The use of such data by the OECD is without prejudice to the status of the Golan Heights, East Jerusalem and Israeli settlements in the West Bank under the terms of international law.

(C) OECD 2019

You can copy, download or print OECD content for your own use, and you can include excerpts from OECD publications, databases and multimedia products in your own documents, presentations, blogs, websites and teaching materials, provided that suitable acknowledgment of OECD as source and copyright owner is given. All requests for commercial use and translation rights should be submitted to rights@oecd.org. 


\title{
LEVELLING THE PLAYING FIELD: DISSECTING THE GENDER GAP IN THE FUNDING OF START-UPS
}

Julie Lassébie (OECD), Sahra Sakha (OECD), Tomasz Kozluk (OECD), Carlo Menon

(Laterite), Stefano Breschi (Bocconi University) and Nick Johnstone (IEA)

\begin{abstract}
This report investigates the gender gap in the funding of innovative start-ups across OECD and BRICS countries using a detailed micro-dataset on start-ups and their founders. Results from empirical analysis show that start-ups with at least one woman in the team of founders are less likely to receive funding by $5-10 \%$. When such start-ups do receive funding, they receive an amount lower by a third compared to start-ups created by male founders. Accounting for founders' characteristics (their educational background and past professional experience) reduces the gap in likelihood to receive funding, but not the gap in funding amounts. A key conclusion is that addressing the gender gap will require a holistic approach, including through - but not restricted to - the education system. The paper concludes by a discussion of potential mechanisms that could explain the observed gap, presents policy options, and proposes an agenda for future research.
\end{abstract}

\section{Acknowledgements:}

The authors are grateful to CIIE and WP1 national delegates for their inputs and to Chiara Criscuolo, Luiz de Mello, Asa Johansson, Dirk Pilat, and Douglas Sutherland for comments on earlier versions of the draft. Angela Gosmann and Jennifer Lee contributed with editorial support. 


\section{Summary and main findings}

- Start-ups and entrepreneurs are at the heart of economic activity. They introduce new and innovative products and services, spur competition, and contribute to productivity growth and job creation.

- However, even start-ups with high-potential and innovative ideas may face barriers to obtaining financing, scaling-up and succeeding. In particular, access to venture capital (VC) may be limited because of asymmetric information, policy barriers or social norms, implying missed opportunities for growth, innovation, and job creation.

- One example of such missed opportunities is that start-ups founded by women are generally less likely to receive funding than male-founded ones. Moreover, even if they receive financing they tend to receive less capital. The reasons for this are not well understood.

- This paper analyses the gender gap in funding opportunities for high-potential start-ups across the OECD and BRICS countries using an innovative micro dataset - Crunchbase. Among the start-ups covered by Crunchbase, less than $6 \%$ are founded by women only, while $15 \%$ have at least one woman among the founders. The gender gap in innovative high-potential start-ups is thus much larger than the gender gap in entrepreneurship in general.

- The analyses confirm the presence of a gender gap in access to venture capital using various measures of start-up financing. In the first analysis, start-ups with at least one female founder are significantly less likely to receive VC funding than start-ups founded exclusively by men. The likelihood of funding for all male start-ups is around $10 \%$ higher than for those with at least one female founder. Accounting for the differences in start-up characteristics (e.g. the sector, the number of founders) and the non-gender characteristics of founders themselves (e.g. past education degree and employment experience), the gender gap is reduced by a third, and even eliminated for start-ups with female founders only.

- Second, conditional on receiving venture capital, the amount of funding received by startups with at least one female founder is a third less than that for male-led start-ups. The penalty associated with the presence of one woman in the team of founders is thus economically large and robust as the gap does not close, even after controlling for company and other founders characteristics.

- Third, the gender gap is also visible when looking at incidences of successful 'exit' (M\&As and IPOs). More specifically, start-ups with at least one female founder are half as likely to be acquired as those founded by men only. In contrast, there is no gender gap in probability to go public via an IPO; however this exit strategy is less common and its importance is declining in certain countries such as the US.

- Country differences exist in terms of gender gap in start-up creation and the likelihood of receiving funding. Italy and the United States have the highest share of start-ups with at least one female founder (i.e. 17\% and 16\%, respectively). Differences between gender in the probability to get any funding is mostly present in Europe where companies with at least one female founder are less likely to get funding by more than $10 \%$. In the United States the difference is smaller and only marginally significant while in Asia no difference is found. However, for those that receive funding the gender gap in funding amount is similar for Europe and the United States. 
- Identifying the underlying mechanisms of the gender gap is crucial for understanding the need for and type of potential policy responses. To the extent the gap is attributable to observable skills differences, closing it would require a holistic approach, including through policies to tackle gender gap in the education system and labour market. In addition, more general policy levers associated with social policy (i.e. parental leave) can have positive implications for female entrepreneurship.

- Still, the overall pervasiveness of the gender gap indicates that unobservable factors play a strong role. These can include gender bias on the investors' side, unintended effects of policies but also personal traits and preferences that cannot be accounted for with available data. Further research can help understand the remaining gender gap and make the case for an effective and appropriate policy response.

- Depending on the channel through which the gender gap arises, relevant policy options could include, for example, adjusting for gender bias in government venture capital funds, business support programmes for women through incubators, and initiatives to address gender bias through promoting women in leadership roles. 


\section{Table of contents}

\section{LEVELLING THE PLAYING FIELD: DISSECTING THE GENDER GAP IN THE

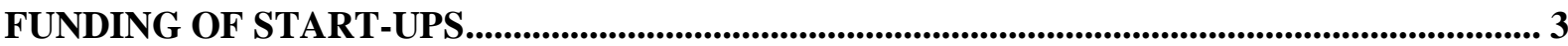

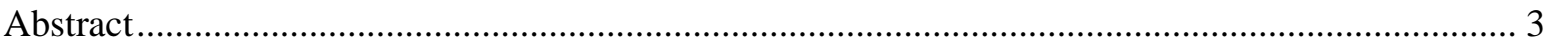

Summary and main findings ................................................................................................................... 4

1. Why worry about the gender gap in start-up funding? ....................................................................... 8

2. Venture capital, innovative entrepreneurship and gender .................................................................. 11

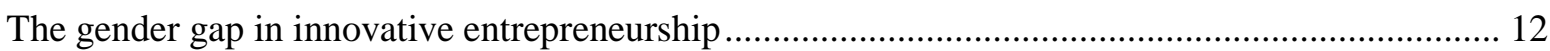

Underlying mechanisms explaining gender gap in entrepreneurship....................................... 14

3. Crunchbase and the gender gap in start-up funding ............................................................. 16

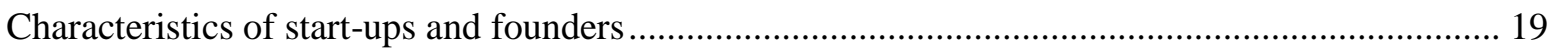

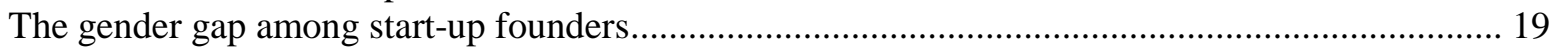

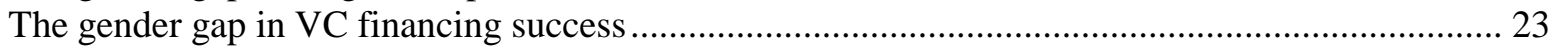

4. Dissecting the gender gap - regression analyses......................................................................................... 25

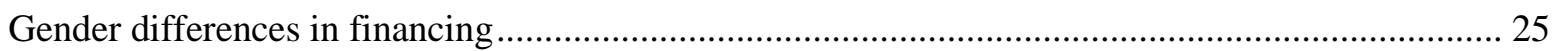

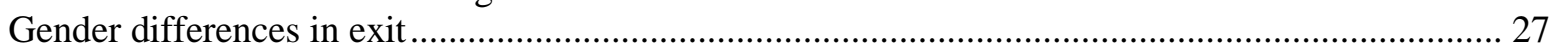

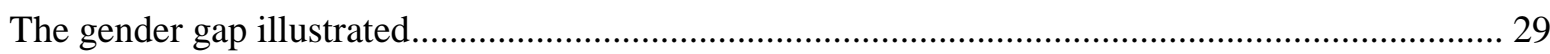

5. Policy implications and ideas for further work ........................................................................... 34

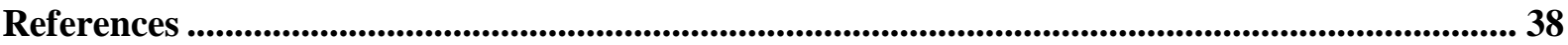

Annex A. Summary statistics for main sample.................................................................................. 43

Annex B. Additional regression tables........................................................................................................ 47

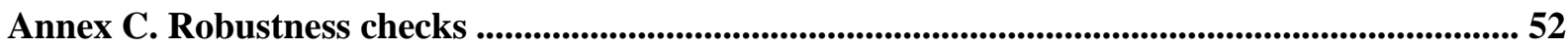

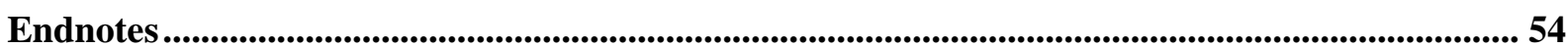

\section{Tables}

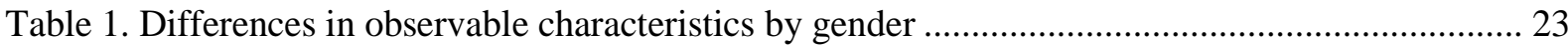

Table 2 . Differences in company characteristics for start-ups with only male founders and those

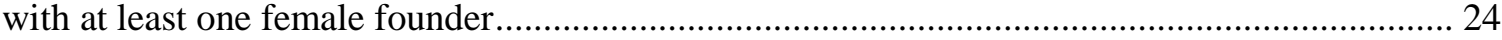

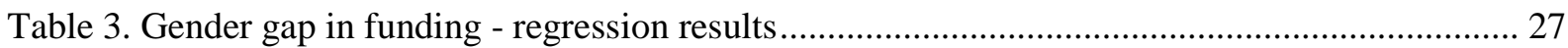

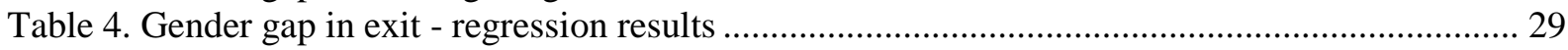

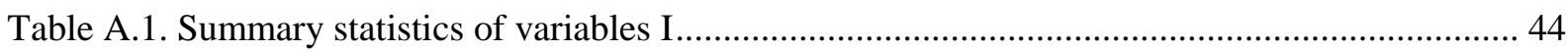

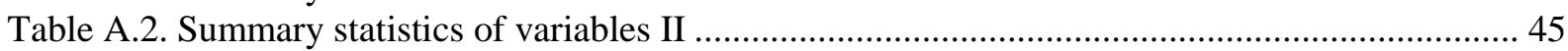

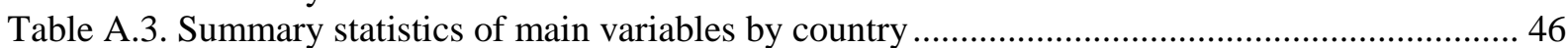

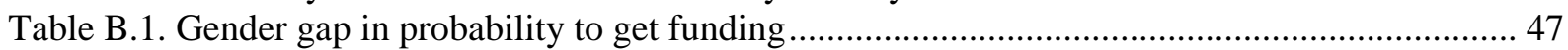

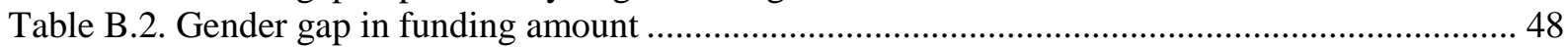

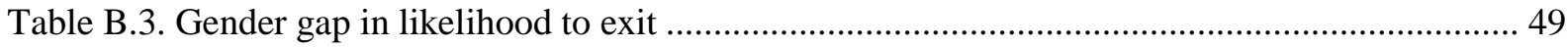

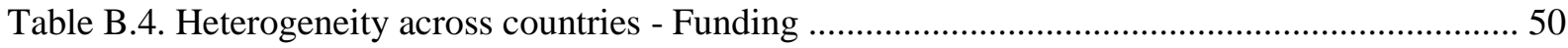


Table B.5. Heterogeneity across countries - Exit 50

Table B.6. Gender gap in funding for start-ups with male and female founders and start-ups with female founders only

Table B.7. Gender gap in exit for start-ups with male and female founders and start-ups with female founders only

Table C.1. Probit results for probability of funding and exit.

Table C.2. Main regressions with country-sector fixed effects

Figures

Figure 1. Venture capital investments across countries 11

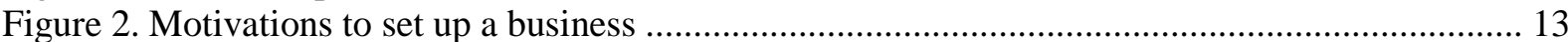

Figure 3. Shares of new entrants in STEM tertiary degrees, by gender ............................................ 14

Figure 4. Comparison of aggregated Crunchbase coverage with the OECD Entrepreneurship

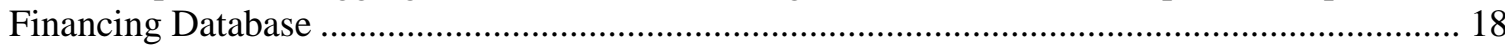

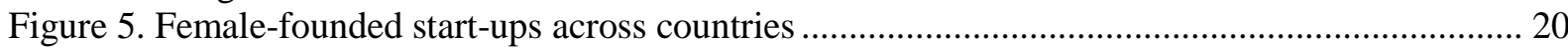

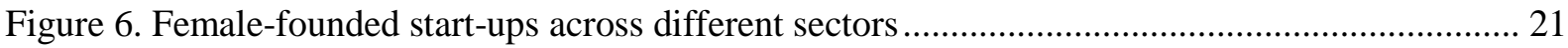

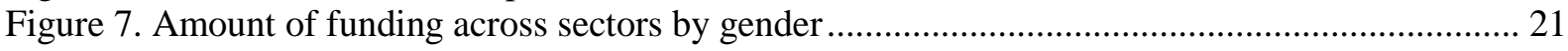

Figure 8. Development of female-founded start-up over time (sample period) …............................... 22

Figure 9. Differences in funding and exit between male-founded companies and those with at least

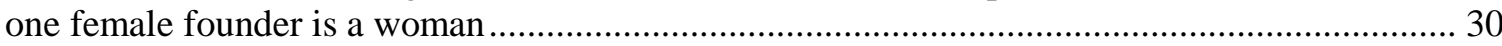

Figure 10. Differences in funding and exit male-founded companies and those in which at least one

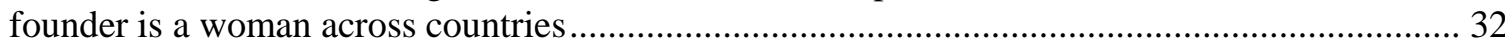

Figure 11. Gender gaps in funding and exit between male-founded companies and those for which at least one founder is a woman for different categories of founders... 


\section{Why worry about the gender gap in start-up funding?}

Entrepreneurs are at the heart of economic activity, innovation, competition, and growth. The early economic literature, from Schumpeter $\left(1911_{[1]}\right)$ to Baumol $\left(1990_{[2]}\right)$, has highlighted entrepreneurship as the driving force for change and innovation in a market economy. Schumpeter's theory of "creative destruction" postulates that the entry of entrepreneurial ventures pushes out obsolete and inefficient firms and brings innovative technologies to the market. Entrepreneurship is also crucial for the vitality of the economy and economic growth through new job and market creation - hence employment and productivity growth (Haltiwanger, 2012[3]; Haltiwanger, Jarmin and Miranda, 2013 ${ }_{[4]}$; Criscuolo, Gal and Menon, 2014 ${ }_{[5]}$; Calvino, Criscuolo and Menon, 2015 $5_{[6]}$ ).

This report focuses on start-up activity. While there is no accepted definition of the term "start-up" in the literature, research on entrepreneurship considers start-ups as all new firms, including a large amount of small businesses with limited growth ambitions. In contrast, the venture capital ( $\mathrm{VC}$ ) literature generally adopts a more targeted and narrower definition of start-ups, which corresponds to a new company with high-growth ambitions. In this work, a start-up is defined as a young, high-potential, and innovating firm.

Access to early-stage financing is a key determinant of success for high-potential start-ups. The early stage of start-up creation, when entrepreneurial ventures match with investors, is particularly crucial (Kaplan and Stromberg, 2003 ${ }_{[7]}$; Song et al., 2008 $\left.{ }_{[8]}\right)$. However, the founder-investor relationship is marked by risk and asymmetry of information. In this respect, what matters most for investors are the fundamentals of the entrepreneur's business proposition and the previous experience of the founders (Amit, Muller and Cockburn, $1995_{[9]}$; Fried and Hisrich, 2018 $\left.8_{[10]}\right)$. Still, if high-potential start-ups fail to succeed because of market failures limiting access to financing, the consequences will be lower growth and innovative potential of the economy.

Start-up activity seems to be characterised by a significant gender gap. Recent studies of high growth start-ups in the United States find that only 10-15\% of them are founded by women (Brush et al., 2014 ${ }_{[11]}$ ). Looking more specifically at start-up funding, several studies have shown that women are extremely under-represented among venture-backed entrepreneurs in the United States. Gompers and Wang $\left(2017_{[12]}\right)$ find that just $10.7 \%$ of US venture-backed founders were women from 2010-2015. Brush et al. $\left(2014_{[11]}\right)$ estimate the number to be $15 \%$ using data from 2011-2013. In fact, female-led firms only receive $7 \%$ of venture capital financing according to the recent study by Gompers and Wang $\left(2017_{[13]}\right)$. In addition to starting their businesses with significantly lower levels of financial capital than men, women raise significantly lower amounts of incremental debt and equity in years two and three (Coleman and Robb, 2009 $\left.{ }_{[14]}\right)$. A significant gender gap is also found in the early-stage angel investment market (Becker-Blease and Sohl, 2007 $[15]$ ). However, this empirical evidence concerns only the US market. While a limited number of papers have looked at the gender gap in start-up funding in other countries (e.g. study of French new firms by Hebert, 2018 $\left.{ }_{[16]}\right)$, no cross-country evidence exists so far on the importance of this phenomenon.

Such a gender imbalance may not only be unfair, but can also result in missed opportunities for economic growth (Bender et al., 2018 $\left.{ }_{[16]}\right)$. If innovative ideas fail to gather sufficient financing and are less successful due to discrimination based on founders' gender, innovation and productivity will suffer. The effects can be quite broad - for example, work 
using 15 years of panel data from the Standard \& Poor's Financial Services' 1500 firms suggests that female managers improve overall firm performance by bringing informational and social diversity benefits to the management team, enriching the behaviours exhibited by managers throughout the firm, and motivating lower-status women in the firm (Dezsö and Gaddis Ross, 2012 $\left.{ }_{[17]}\right)$. However, the gender gap might also reflect rational investor behaviour driven by the desire to maximise returns. In this case, the differences in funding between male and female-founded companies may simply reflect the gender gap in characteristics positively associated with start-up success - such as STEM education. Thus, the gender gap in the financing stage may actually arise from the education system, the labour market or some deeper social institutions - also called in the literature statistical discrimination - rather than investor taste-based discrimination.

Uncovering the mechanisms and implications of the venture funding "gender gap" continues to be an important area of research. The objective is to identify if, where and how policy action to "level the playing field" may be desirable and effective. For example, the policy response will be very different if the gender gap results from outright discrimination by investors - meaning that good, promising ideas fail to get financing because of an unfounded assumption that women entrepreneurs do not deliver - or from statistical discrimination as described above.

The first measure against any outright discrimination is legal prosecution. However, despite many national and international non-discriminatory laws in place, identifying whether and, if this is the case, proving that - discrimination in the venture capital market causes the gender gap is challenging since the financing process is not directly observable. In comparison with many other financing decisions, the process by which a venture capital fund selects between alternative business propositions is structured in a manner that does not allow for formal evaluation of the effects of specific selection criteria. As such, understanding the decision-making of investors is complicated by the inherent asymmetry of information.

Among the few examples of studies which have sought to assess the role of different factors on selection, Kanze et al. $\left(2018_{[18]}\right)$ analysed video transcripts of the Q\&A sessions during venture capital pitches. Their study revealed that framing has important implications for the selection decision. Most pertinently for this study, they found that venture capitalists posed different types of questions to male and female entrepreneurs. They tended to ask men questions about the potential for gains and women about the potential for losses. Such types of experiments can be helpful to understand the origins of the gender gap and whether it is linked to conscious or unconscious discrimination.

Pro-active measures to bridge the gender gap, such as government-funded venture capital funds targeting women, nudging investors or awareness campaigns may also be considered and would not require legal proof of discrimination. On the other hand, if the number, qualifications or ideas of female founders are weaker than those of male founders - giving grounds for investors' preference in choosing against them - the policy interventions may be more effective upstream, in the education system or labour market.

Disentangling such effects can be complicated. For example, women and men may, on average, demonstrate business objectives or personal traits which are valued differently by investors. Moreover, actual but also perceived discrimination by investors could lead to self-censoring in women's choices to apply for start-up funding as well as broader career choices. The gender gap in the rates of start-up creation, start-up funding, and exit may thus reinforce each other: the low number of women founding a start-up translates into a low number of VC-backed female start-ups, and in turn the perspective to face difficulties in 
the financing market may discourage women to start new ventures. Similarly, the perception that less funding will be received even amongst those who are successful may discourage women from proposing more ambitious business ventures.

In practice, another reason why identifying the actual drivers of the venture capital funding gap has proved challenging is the lack of solid, reliable and timely data. First, standard data sources only provide information on start-ups that have successfully raised capital, as it is challenging to systematically identify start-ups in pre-financing stage and to compare those that have received funding and those that did not. Second, traditional datasets on VC financing often do not contain detailed information on firms' age and size which makes it difficult to identify young and high-growth companies. Third, papers investigating gender gap in venture capital funding utilise only country-specific data - mostly from the United States. This does not allow cross-country comparisons, which is particularly restrictive when examining questions where cultural differences are potentially important. To the best of our knowledge, this is the first paper that is able to link a rich set of socio-demographic characteristics of start-up founders to their performance and capital financing in a crosscountry setting.

The objective of this paper is to shed light on some of the determinants of success in earlystage venture capital financing bids. In particular, the work focuses on the effect of founders' gender on the investors' funding decisions. A micro-dataset called "Crunchbase" is used to characterise, analyse and explain the gender gap in funding of high-growth innovative start-ups across OECD, Colombia and BRICS. The sample used for this report contains 70362 start-ups across the OECD, Colombia and BRICS economies. About half of these received venture capital funding. Conditional on receiving VC, start-ups received on average around USD 12 million.

The rest of the paper proceeds as follows. Section 2 presents a brief overview on the literature. Section 3 describes our data and variables of interest. Section 4 shows the empirical results while Section 5 discusses policy implications and proposes follow up research. 


\section{Venture capital, innovative entrepreneurship and gender}

Venture capital (VC) is broadly defined as a form of equity financing particularly important for young companies with innovation and growth potential but untested business models and no track record (OECD, 2017 $\left.{ }_{[19]}\right)$. It includes equity investments made to support the pre-launch, launch and early stage development phases of a business. It is particularly relevant for firms with limited access to other forms of financing notably innovative, highpotential (but also high risk) start-ups with no or few physical assets which could serve as collateral and no credit history. In exchange for the investment, VC providers become coowners of the funded firm, participate in strategic decisions, and provide mentoring. Venture capital seeks to generate big returns on small initial investments and is particularly present in sectors such as Information and Communications Technology (ICT) or life sciences. Hence, venture capital is primarily linked to high potential start-ups in selected sectors. For instance, in the United States, where VC markets are relatively well developed, only $0.31 \%$ of new start-ups are backed by VC (Gornall and Strebulaev, 2015 200$]$ ). In fact, while its importance is increasing, in most OECD countries venture capital is below $0.05 \%$ of GDP (OECD, 2018 $\left.{ }_{[21]}\right)$. Two countries stand out though, the United States and Israel with venture capital representing more than $0.35 \%$ of GDP (Figure 1).

\section{Figure 1. Venture capital investments across countries}

As \% of GDP, 2017 or latest available

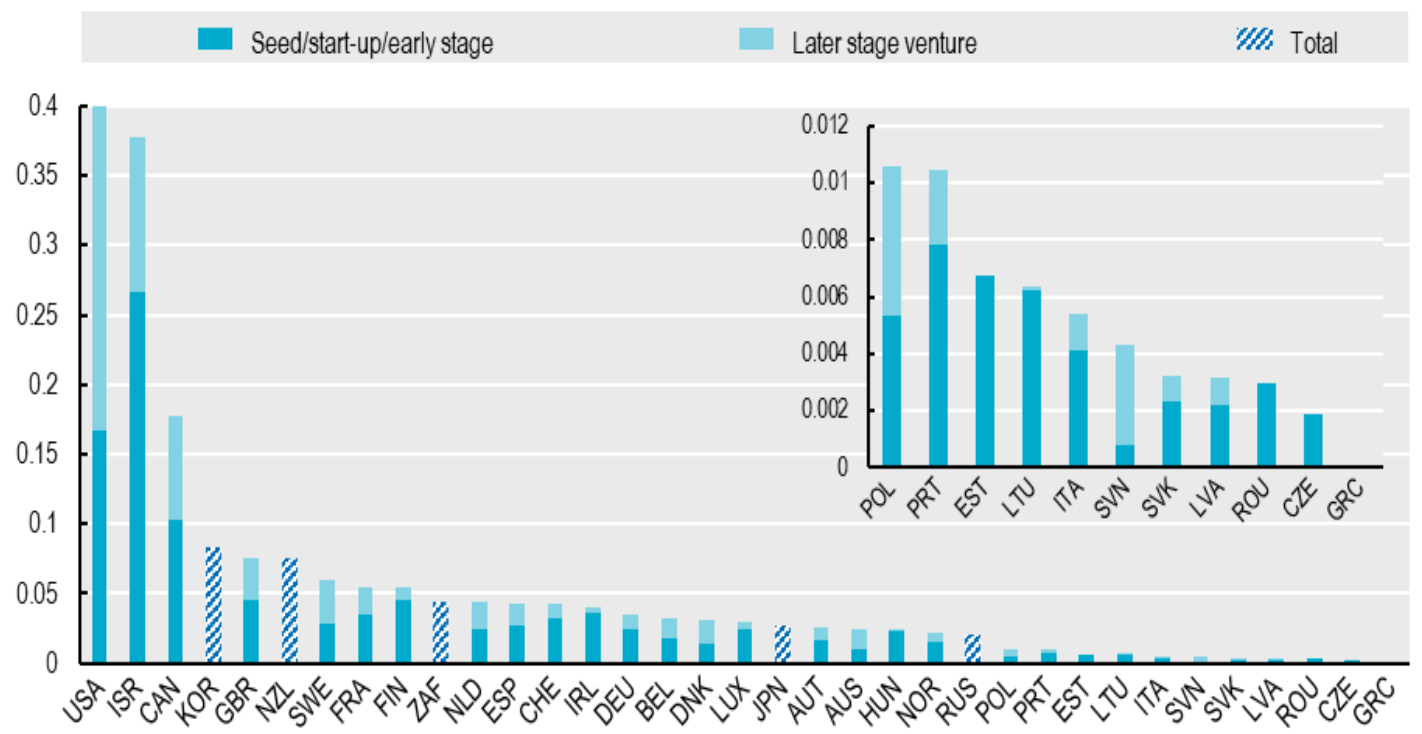

Source: OECD Entrepreneurship Financing Database (EFD).

Even though only a tiny proportion of new firms receive $\mathrm{VC}$ funding, it is among this small number of VC-backed companies where innovation, jobs creation, and growth are particularly spectacular. While many VC-backed start-ups may fail, $42 \%$ of US public companies founded between 1974 and 2013 are VC-backed, and they accounted for 85\% of R\&D expenditures in 2014 (Gornall and Strebulaev, 2015 ${ }_{[20]}$ ). Many recent tech giants such as Amazon, Facebook, Google, Dropbox, Instagram, Snapchat, Spotify, Uber, WhatsApp and Alibaba were initially VC-backed. Moreover, Puri and Zarutskie (2012 $\left.{ }_{[22]}\right)$ 
show that employment generated by start-ups that have received VC accounts for $5.5 \%$ of employment per year in the United States on average over the period 1981-2005.

\section{The gender gap in innovative entrepreneurship}

Entrepreneurship, in general, is characterised by a significant gender gap. For example, in the European Union the proportion of women in self-employment is under 10\% compared with $17.5 \%$ for men. Similarly on average in the OECD, over 2012-16 some 5\% of women declared themselves as working towards opening a business, while the share was $7.4 \%$ for men.

Looking at the different growth phases of a business, proportion of women drops even further. Indeed, women typically tend to run smaller businesses and employ less workers, while they are as likely as men to offer an innovative product or service (OECD/EU, $2017_{[23]}$ ). In the Norwegian case, a study illustrates the funnel for female entrepreneurs: almost as many women as men are willing to become entrepreneur, however far less women than men actually open a business. Furthermore, among companies that have survived after five years, only $19 \%$ have female entrepreneurs, and this proportion is down to $10 \%$ for companies with more than 10\% annual revenue growth (Grünfeld et al., 2019[24]).

There are indications that the motivation to become an entrepreneur may differ between gender (Figure 2). Empirical evidence suggests that gender differences start at a much earlier stage (Council of Economic Advisers, 2015 [25]). The report by Lawless and Fox $\left(2013_{[26]}\right)$ shows that among high school and college students, girls are less likely than boys to envision themselves as entrepreneurs. They are also less confident in their entrepreneurial and business abilities and knowledge. These attitudes become entrenched early in life because of the different expectations society has of girls versus boys (Inzlicht and Schmader, 2011 $\left.1_{[27]}\right)$.

On the other hand, girls with parents in business are more likely to be interested in business, suggesting that early exposure to business as a career can raise awareness of entrepreneurship as a possible career. Beyond this family relationship, outreach efforts do appear to generate interest in business among girls. For instance, girls who participate in leadership roles in activities outside school are also more likely to express interest in a career in business suggesting that more opportunities to participate in such activities may help foster girls' business interest (Marlino and Wilson, 2002 ${ }_{[28]}$ ).

Similarly, early exposure to innovation for children has a positive impact on their propensity to become inventors. Bell et al. $\left(2017_{[29]}\right)$ show that children whose families move to a high-innovation area when they are young are more likely to invent later in life. However, these results are gender-specific: girls are more likely to invent if they grow up in an area with more women (but not men) inventors. This points to the importance of role models and network effects. 


\section{Figure 2. Motivations to set up a business}

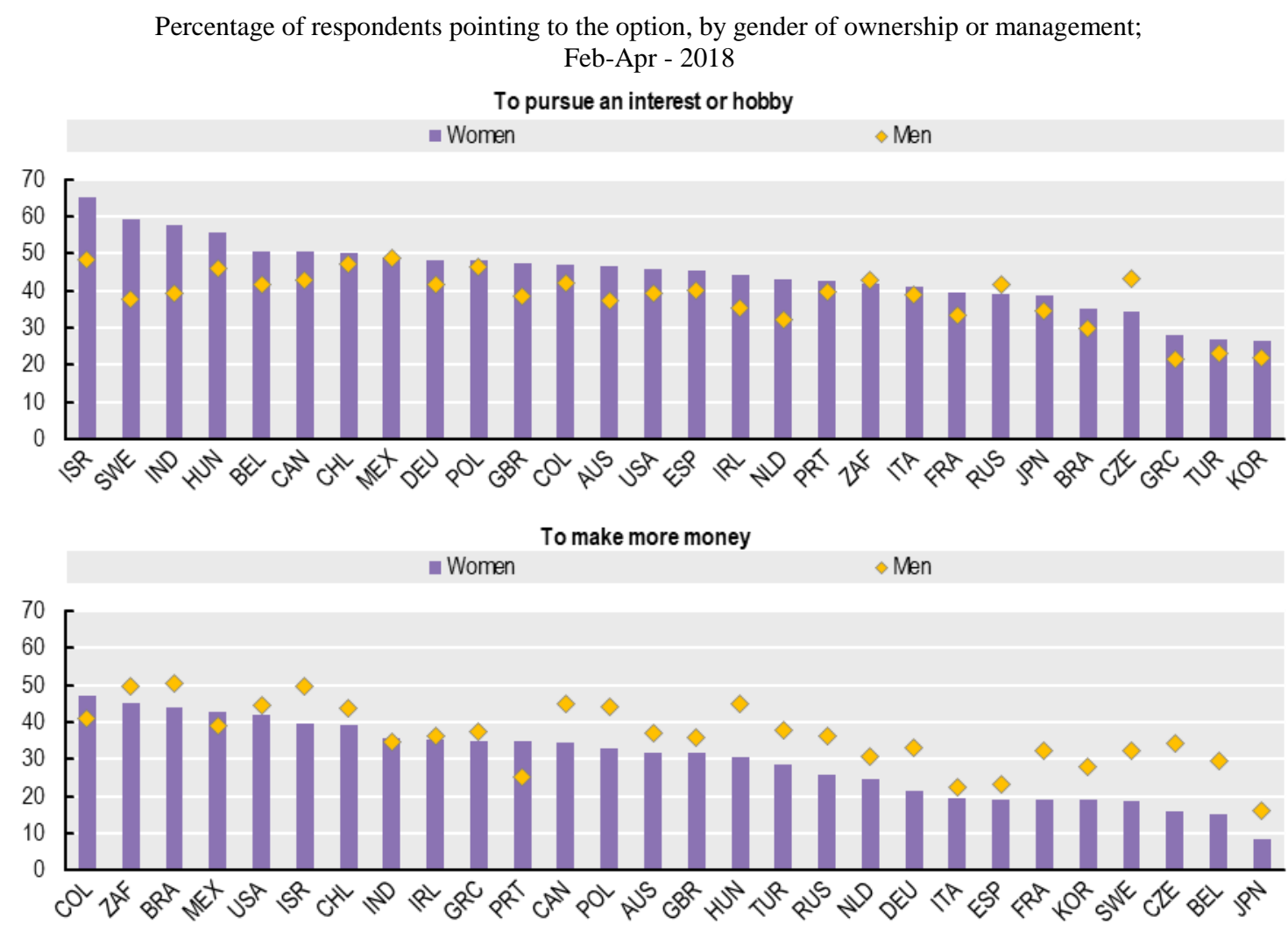

Note: Information on data for Israel: http://oe.cd/israel-disclaimer Source: The Future of Business Survey (FOBS), Facebook-OECD-World Bank.

As noted above, venture capital is particularly associated with high-technology firms and there are significant gender gaps in study fields traditionally related to high technologies particularly science, technology, engineering and mathematics (STEM). Women are generally less likely to choose STEM related subjects in their tertiary education (Figure 3), despite only small differences in average performance on maths and science before entering university $\left(\mathrm{OECD}, 2016_{[30]}\right)$. The difference in STEM degree choices is likely to reflect in part differences in boys' and girls' expectations of future science careers. For example, on average across OECD countries, $12 \%$ of 15 year old boys are likely to aspire a career as a scientist, architect or engineer, while only $5 \%$ of girls do the same (OECD, 2016 [30]). Similarly, a career in information and communication technology (ICT) is an aspiration for some $5 \%$ of boys and less than $1 \%$ of girls. Furthermore, parents' expectations on STEM related careers tend also to differ significantly by gender (OECD, 2015 $\left.{ }_{[31]}\right)$. There is some evidence that this gap have declined recently (Ernst \& Young (EY), 2018 [32]). Still, overall, the participation of women in STEM is significantly higher than the participation in venture capital financed entrepreneurship. 
Figure 3. Shares of new entrants in STEM tertiary degrees, by gender

2016

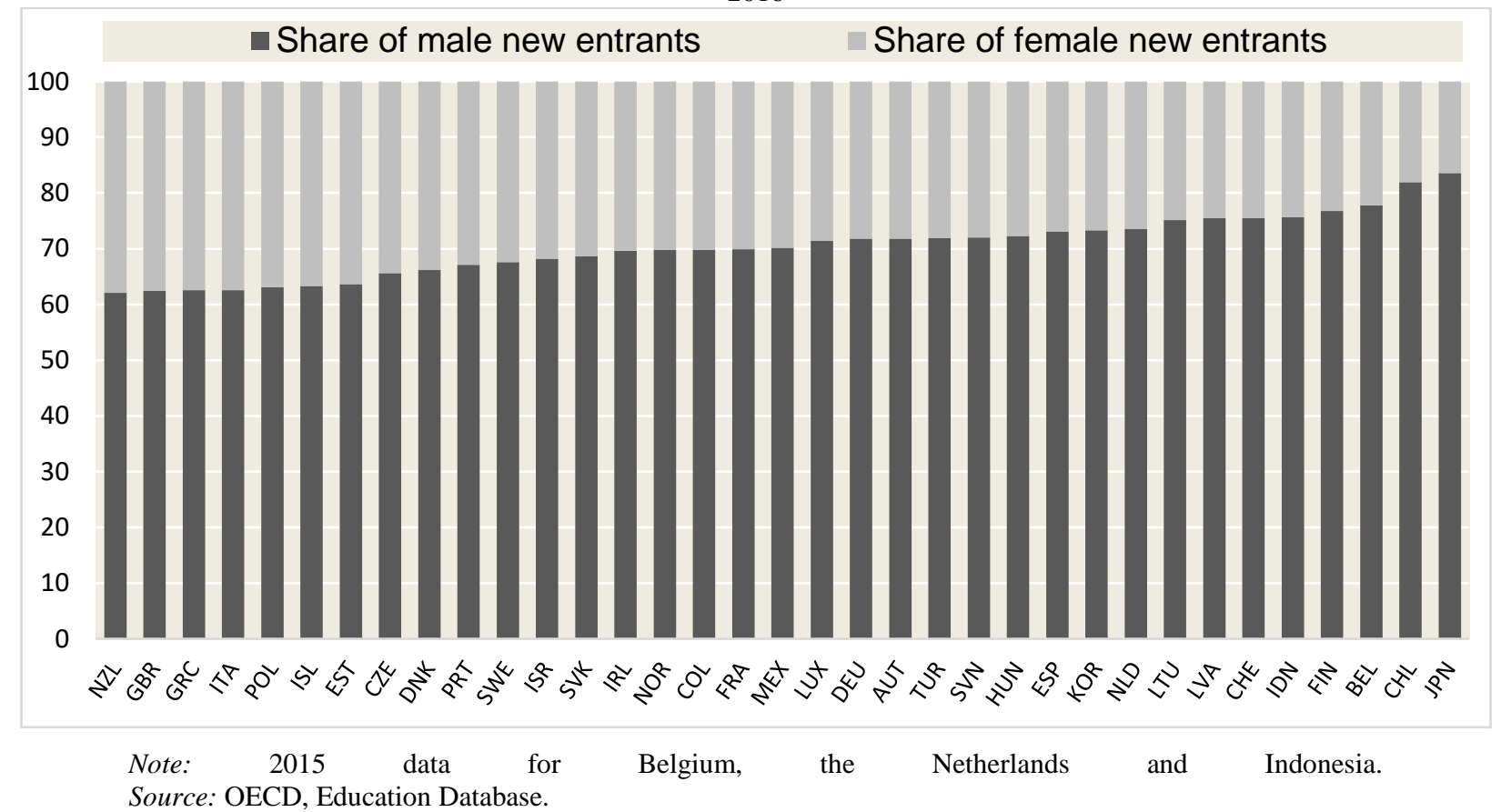

Finally, the financing of entrepreneurial activity is also characterised by a significant gender gap. Regarding debt financing, female entrepreneurs face more limited access to credit and even if they receive funding, they are confronted with higher interest rates (Bellucci, Borisov and Zazzaro, 2010 [33]; Alesina, Lotti and Mistrulli, 2013 [34]). Since female entrepreneurs are less likely to receive private equity funding (Becker-Blease and Sohl, 2007 $[15]$ ) and bank financing (Eddleston et al., 2016 $\left.{ }_{[35]}\right)$ they rely more on personal sources of debt and equity (Coleman and Robb, 2009 ${ }_{[14]}$ ). In fact, female-led firms only receive $7 \%$ of venture capital financing according to a recent study by Gompers and Wang $\left(2017_{[13]}\right)$.

\section{Underlying mechanisms explaining gender gap in entrepreneurship}

The underlying explanations for a gender gap in entrepreneurship can either be entrepreneur-driven or investor-driven (Kanze et al., 2018 ${ }_{[18]}$ ). Much of the literature on entrepreneurship that draws upon insights from the psychology literature attribute the funding gap to differences between personality attributes ascribed to women and those ascribed to entrepreneurs. In particular, there is a large amount of laboratory-based research documenting gender differences in risk attitudes (Eckel and Grossman, 2002 [36]; Dohmen et al., 2011 [37] $)$, confidence (Barber, 2001 ${ }_{[38]}$ ), competition (Buser, Niederle and Oosterbeek, 2014 $\left.{ }_{[39]}\right)$ as well as attitudes toward negotiation (Exley, forthcoming $\left.{ }_{[40]}\right)$. For instance, Becker-Blease and Sohl $\left(2007_{[15]}\right)$ show that women seek angel financing at rates substantially lower than that of men, but have an equal probability of receiving investment conditional on searching for funding. Differences in aspirations may also play a role. Women are more likely to be associated with less capital-intensive businesses and less aggressive growth efforts (Kanze et al., 2018 ${ }_{[18]}$ ). 
Another supply-side explanation relates to a possible mismatch between education or past professional experiences and the type of founders' background that leads to successful entrepreneurship. Evidence from the United States seems to suggest that this cannot be the entire explanation. Indeed, the representation of women in MBA programmes as well as advanced science and engineering degrees has been substantially higher than their representation in the entrepreneurial sectors for the past two decades. Furthermore, the under-representation of women as venture-backed entrepreneurs is not met by a similar under-representation in other highly-compensated professional fields such as medicine or law, nor in jobs with similar human-capital profiles such as investment banking or consulting.

On the other hand, the results of work focusing on investor-driven explanations indicate that financiers may be reluctant to fund female entrepreneurs due to (un)conscious, implicit bias. For instance, they often make their decisions based on speech patterns and non-verbal gestures during the pitch, lowering the willingness of investors to fund female entrepreneurs seeking capital (Balachandra et al., 2017 [41] $^{\text {; Clark, 2008 }}$ [42] $_{\text {; Kanze et al., }}$ $\left.2018_{[18]}\right)$. Furthermore, Brooks et al. $\left(2014_{[43]}\right)$ provide experimental evidence that investors prefer entrepreneurial pitches presented by male entrepreneurs compared to pitches presented by female entrepreneurs, even when the content is the same. Finally, there seems to be some degree of homophily: male investors express less interest in female entrepreneurs compared to observably similar male entrepreneurs. In contrast, female investors express more interest in female entrepreneurs (Ewens, forthcoming ${ }_{[44]}$ ). 


\section{Crunchbase and the gender gap in start-up funding}

Research on venture capital funding uses a variety of data sources ranging from commercial databases such as VentureSource, ThomsonOne or AngelList (for data on angel investments), to hand-collected survey data (Rin, Hellmann and Puri, 2013 $3_{[45]}$ ). Several authors have studied the coverage of such databases and have shown that they do not cover the universe of VC deals but rather report only a sample of VC investments (see Rin, Hellmann and Puri, 2013 ${ }_{[45]}$ for more details on existing literature on venture capital and a description of the data generally used). The main limitations of commonly used datasets are: 1) that they do not contain information on firms seeking but not receiving VC and 2) that they do not include details on the companies and their founders. As a result it is not possible to investigate the issue of gender gap in $\mathrm{VC}$ financing using these databases. Finally, these datasets mainly focus on the US market, and cross-country evidence on the importance of the phenomenon cannot be assessed.

The main source of data used in this paper is Crunchbase. Crunchbase, a popular online platform, connects venture capitalists with seed stage start-ups. Companies create profiles on Crunchbase describing their businesses and founding teams - including their education background and experience. Accredited investors can register on the platform and subsequently connect with companies seeking funds.

The platform and database was created in 2007 but the scope and coverage have increased significantly over the past few years. As reported by Kaufmann Foundation (a major nonprofit foundation supporting entrepreneurship education programmes), the database is increasingly used by the venture capital industry as a "the premier data asset on the tech/startup world". Dalle, den Besten and Menon (2017 $[46]$ present a detailed discussion of the database and its potential for economic, managerial, and policy-oriented research.

Crunchbase has major advantages. First, it is partially crowd-sourced, i.e., users can add and revise contents, which adds to the comprehensiveness and timeliness of the database. In particular, it has developed partnerships with VC firms in different countries that share their portfolio data. The information is also cross-validated by the Crunchbase analyst team with artificial intelligence (AI) and machine learning algorithms, in order to ensure accuracy and scan for anomalies. Furthermore, Crunchbase is becoming a reference for professionals seeking to invest in start-ups, and young firms looking for funding have strong incentives to appear in the database. Therefore, the database also includes start-ups not receiving $\mathrm{VC}$, but presumably actively looking for funding, and thus permits a meaningful comparison between both types of firms. Finally, it contains detailed information on companies (i.e. size), their founders (i.e. age, education), and their staff, allowing an analysis of the determinants of the gender gap.

Crunchbase contains information on distinct entities located around the world ${ }^{1}$; the majority of entities are companies, while the remaining ones are VC investors, schools, or business groups. Companies are classified into one or more of 45 different economic activity groups, which henceforth are referred to as "sectors". ${ }^{2}$ This classification does not follow any major industry classification system, but is especially customized to the startup world and to emerging sectors. For approximately $70 \%$ of companies, the database contains information on the founding year, which allows detecting young and innovative start-ups. Furthermore, the database covers VC deals ${ }^{3}$, IPOs, and acquisitions, allowing for an investigation of the determinants of start-ups' success (for details, see Dalle, den Besten 
and Menon, 2017 $7_{[46]}$ and Breschi, Lassébie and Menon, 2018 $\left.8_{[47]}\right)$. For this report, the sample is restricted to firms created between 2000 and 2017, for three reasons. First, the report focuses on the financing of young companies. Second, since Crunchbase was created in 2007, backfill bias (i.e. a tendency to omit or misreport firms that once sought funding, but failed and ceased doing so) is stronger the longer the time period considered in the past. Finally, information on financing and exit is limited for the earlier periods.

Crunchbase also covers detailed information on the socio-demographic characteristics of the founders of start-up companies. This includes their full name, current position title, education (degree and subject studied), employment history, the university in which they studied, and gender. This information has been complemented and cross-validated with data taken from Breschi et al. $\left(2017_{[47]}\right)$ or other datasets such as PATSTAT (for information on patents applications of start-up founders).

In Crunchbase, most people are classified as founder, co-founder, or CEO, and gender information is reported for $99 \%$ of individuals. The sample is, thus, restricted to companies for which the gender of at least one founder, co-founder, or CEO is reported. Roughly half of the start-ups in the sample have a single founder, in which case it is straightforward to categorize a start-up as "female-led" or "male-led". Some of the start-ups in our sample have multiple founders. In this case, a dummy variable indicates whether at least one founder is a woman.

Education and employment history are not available for the full sample, but the data allows the analysis of the "curriculum vitae" of approximately 40000 founders of more than 25000 start-ups. The information on degree type, subject, and previous job titles is not standardised. Therefore textual data have been processed using data mining techniques to extract information that can be used in quantitative analyses. In particular, each education entry has been assigned a degree type using a keyword search on the degree information reported by individuals, and a subject field following ISCED fields' classification using a supervised machine learning technique that can be used for natural language processing. Past professional experiences have also been grouped into meaningful categories using keyword search on job titles (Annex A shows summary statistics of these variables).

Finally, the study is not limited to start-ups that successfully raised capital as in most of the past work. Instead, the dataset contains a large set of start-ups trying to raise capital - some of which succeeded and some of which failed (so far). This allows an analysis of the population of founders seeking financing in a way that has not previously been possible, and a direct investigation of whether and why gender appears to be an important determinant of fundraising success.

Academic interest in Crunchbase has recently grown and research using this database has been published in major journals. Examples include (but are not restricted to) Alexy et al. $\left(2011_{[48]}\right)$, Bertoni and Tykvová $\left(2015_{[49]}\right)$, and Block, De Vries and Sandner $\left(2012_{[50]}\right)$. For a more detailed literature review, see Dalle, den Besten and Menon (2017 $\left.{ }_{[46]}\right)$, who discuss more than 80 academic studies in the field of economic, managerial, and entrepreneurship research based on the Crunchbase data.

A benchmarking of Crunchbase against the OECD aggregate Entrepreneurship Financing Database shows that Crunchbase presents a similar, or if anything a better, coverage of VC deals and start-ups (Figure 4), in particular across OECD countries and five large emerging economies (Brazil, the People's Republic of China (hereafter "China"), India, Russia Federation, South Africa), starting in 2009 for the US and 2012 for other countries. For this 
reason, the analyses presented in this report are limited to companies operating in OECD, Colombia and BRICS economies.

Figure 4. Comparison of aggregated Crunchbase coverage with the OECD Entrepreneurship Financing Database

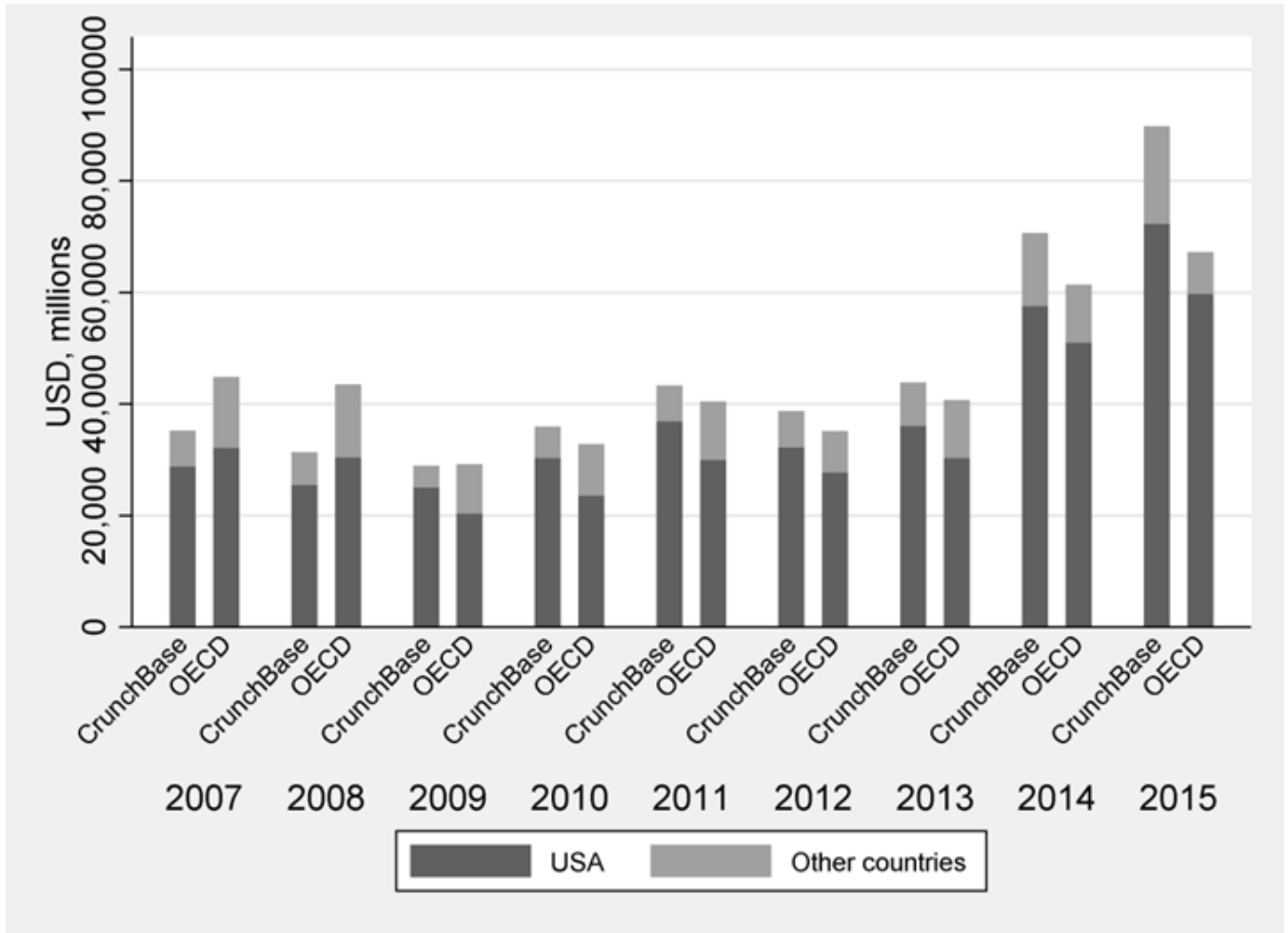

Note: Comparison of aggregate statistics on Venture Capital investments in Crunchbase and OECD Entrepreneurship Financing Database by year for the US and other countries.

Source: http://www.crunchbase.com and OECD Entrepreneurship Financing Database

Crunchbase presents a number of limitations. First, Crunchbase cannot avoid selection, insofar as start-ups initially may also seek other platforms or ways to receive financing. This does not necessarily pose a problem for investigating the gender gap, as long as there are no grounds to think that this self-selection is related to gender. On the contrary, if female founded start-ups are targeted by public investment programmes, and if female entrepreneurs who apply to and receive this type of funding choose not to register on the Crunchbase platform, the estimates of the gender gap presented in this paper may be distorted. However, Crunchbase contains several instances of public VC funding, and in the aggregate female-founded start-ups do not significantly appear to be the primary target of such schemes (Breschi et al., forthcoming $\left.{ }_{[51]}\right)$. This alleviates partly the concern raised above. Furthermore, start-ups backed by public VC funding may still have incentives to appear in the database, in order to look for further rounds of financing, or if the size and competitiveness of the public funding is lower than what private VC funds may offer.

Second, the historical dimension of the database is mainly limited to the snapshot of companies that have been active since the creation of Crunchbase. While Crunchbase 
contains information on start-ups receiving VC before the creation of the database, backfill bias may hamper clear identification. Start-ups that failed and ceased operations are less likely to have left information in the database. Therefore, spurious trends of deal numbers or investments may appear in the data. This calls for caution in the examination of trends over time. Third, while the coverage of Crunchbase for OECD countries appears sufficiently exhaustive for recent years, at its creation the database had a better coverage of start-ups and VC deals in the US than in other OECD countries. To address the issue, the regression analyses presented in this work control for country and cohort unobserved heterogeneity. Finally, the amount invested in the VC deal is not disclosed in around 20\% of cases.

\section{Characteristics of start-ups and founders}

The cleaned sample contains 70362 start-ups across the OECD, Colombia and BRICS. Descriptive statistics for this sample of firms are summarized in Table A.1 and Table A.2 in Appendix. About half of start-ups in the sample received venture capital funding. Conditional on receiving VC, start-ups received on average around USD 12 million. Moreover, these start-ups have an overall 'exit' rate of $13 \%$, with around $15 \%$ of them exiting via IPO ( $2 \%$ of total sample) and the rest exiting via acquisition (11\%). More than half of the start-ups have a single founder (Table A.1). Of these founders, $70 \%$ are between 20-35 years old (Table A.2). Some $80 \%$ of start-ups have at least one founder with a Bachelor's degree and $13 \%$ have at least a founder with a $\mathrm{PhD}$. The highest share of founders with a $\mathrm{PhD}(20 \%)$ can be found in the biotechnology sector. In terms of education, less than half of the founders have a STEM degree. Within the STEM field, $20 \%$ of the founders possess a computer science degree (4 600 start-ups), 15\% have an engineering degree (4 200 start-ups) and only 1520 of start-ups have at least one founder with a natural science degree. Overall, $40 \%$ of founders have either a business, finance or law background. In terms of employment experience, around $20 \%$ of founders have been a CEO before start-up founding while a relatively large share of founders have a senior management (management-suite) background. About $40 \%$ of the founders in the sample can be considered as having worked in business before founding the start-up, 30\% were computer scientists, while $10 \%$ come from the financial sector.

\section{The gender gap among start-up founders}

Overall $15 \%$ of start-ups have at least one woman as the founder, while under $6 \%$ have only female founders, with significant variation across countries and sectors (Figure $5^{4}$ and Figure 6). The average is in line with the results of the Diana Project survey in 2011-2013, which found that $14.8 \%$ of VC-financed firms had a female executive (Brush et al., $\left.2014_{[11]}\right)$. The highest share of female-founders are in Italy and the United States, while the lowest are in the Denmark, Netherlands, and Sweden. What is particularly striking is that this share has been roughly stable since 2011 (Figure 8).

Women and men founders differ in terms of personal characteristics available in Crunchbase (Table 1). Women are less likely to create start-ups at an early age compared to men, and are less likely to have a registered patent. Women also have a lower share of professional experience as a computer scientist or engineer compared to men. Interestingly, overall men and women have similar levels of educational attainment (e.g. $\mathrm{PhD}, \mathrm{MSc}$, MBA, BSc). However, fields of education differ: for instance, male founders in the sample are more likely than female founders to hold a STEM degree (a statistically significant difference of 20 percentage points between men and women). 
Consistent with this observation, Figure 6 shows that "STEM-related" industries are more dominated by male founded companies. Female-led start-ups, i.e. start-ups in which at least one founder is a woman, tend to be in areas generally perceived as less high-tech, such as - lifestyle, education, and fashion rather than - hardware, software, information technologies. The significant variation in start-up creation across sectors observed in Figure 6 is not clearly related to the funding gap. For example, female-founded start-ups are more common in design, where exclusively male-founded start-ups still receive a higher amount. On the other hand, start-ups with at least one female founder are relatively few in science and engineering, where the gender gap in funding is much lower (Figure 7).

\section{Figure 5. Female-founded start-ups across countries}

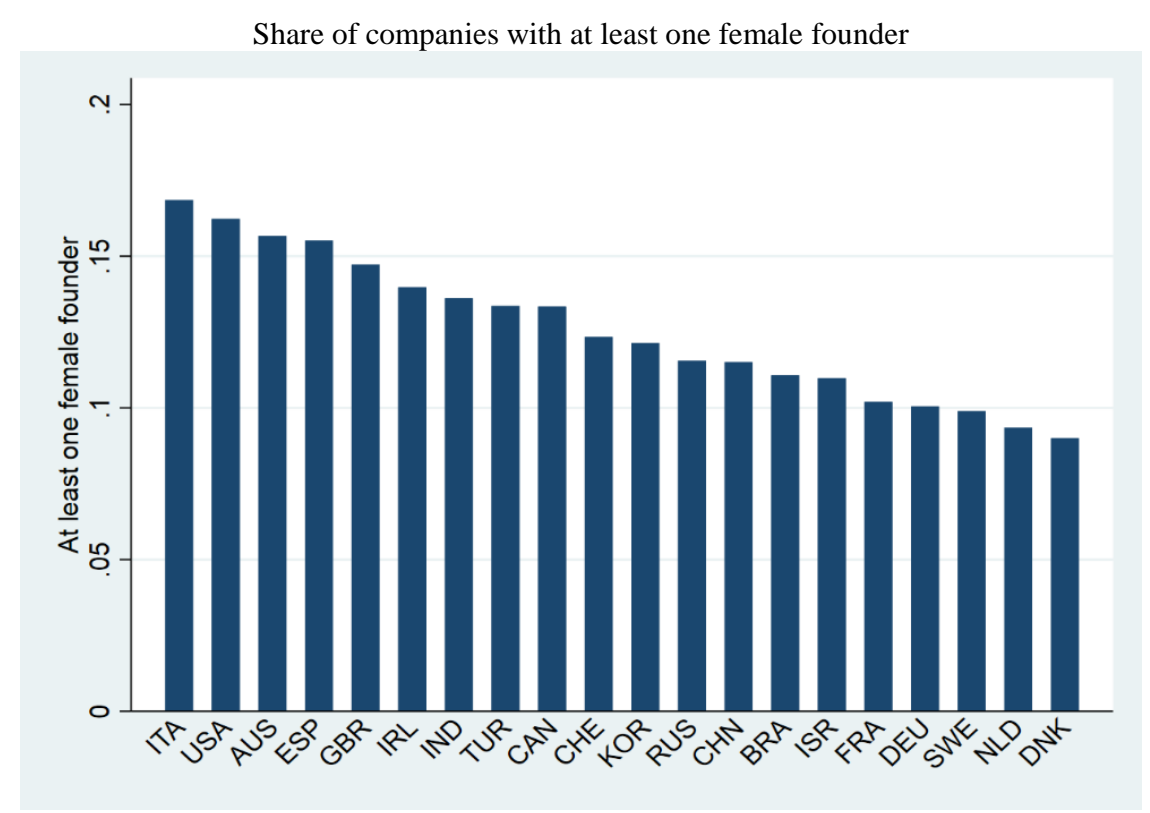

Note: Graph limited to top 20 countries in terms of number of start-ups. The sample is limited to companies in OECD, Colombia and BRICS countries, founded between 2000 and 2017. Figure A.1 in Appendix shows the same statistics for smaller countries in terms of number of observations. Source: Authors' elaborations on www.crunchbase.com 


\section{Figure 6. Female-founded start-ups across different sectors}

Share of companies with at least one female founder

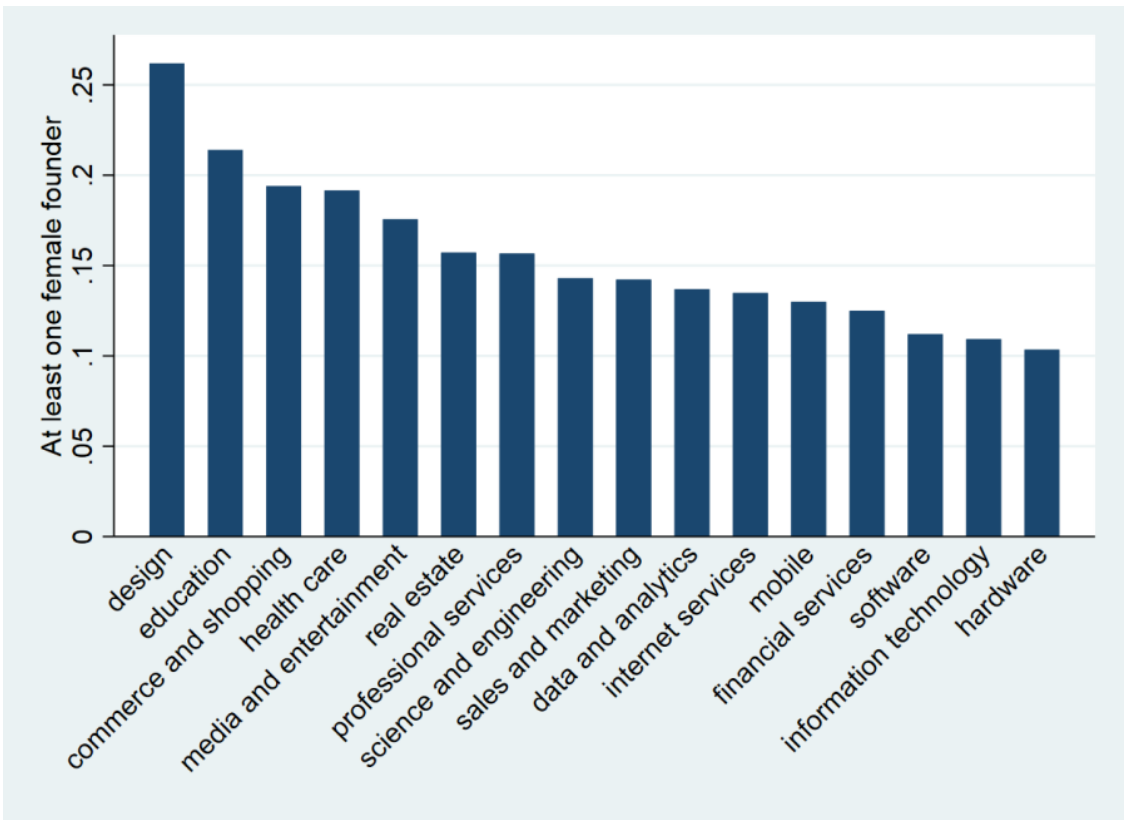

Note: Sample limited to firms created between 2000 and 2017, located in OECD, Colombia, and BRICS countries. Graph restricted to top 20 technological fields in terms of numbers of companies. Source: Authors' elaborations on www.crunchbase.com

Figure 7. Amount of funding across sectors by gender

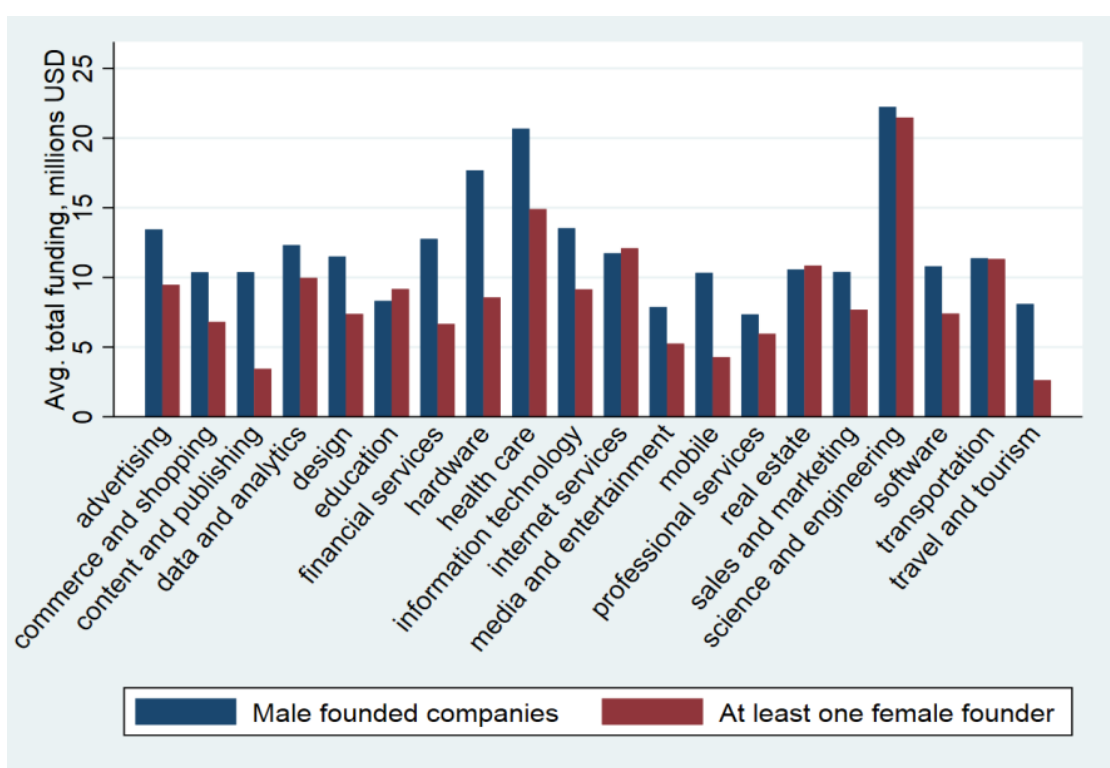

Note: Sample limited to firms created between 2000 and 2017, located in OECD, Colombia, and BRICS countries, and having received at least one round of VC investment. Graph restricted to top 20 technological fields in terms of numbers of companies. Total funding amounts exceeding USD 225 millions $\left(99^{\text {th }}\right.$ percentile) are excluded to ensure that analyses are not driven by few companies receiving large deals.

Source: Authors' elaborations on www.crunchbase.com 
Figure 8. Development of female-founded start-up over time (sample period)

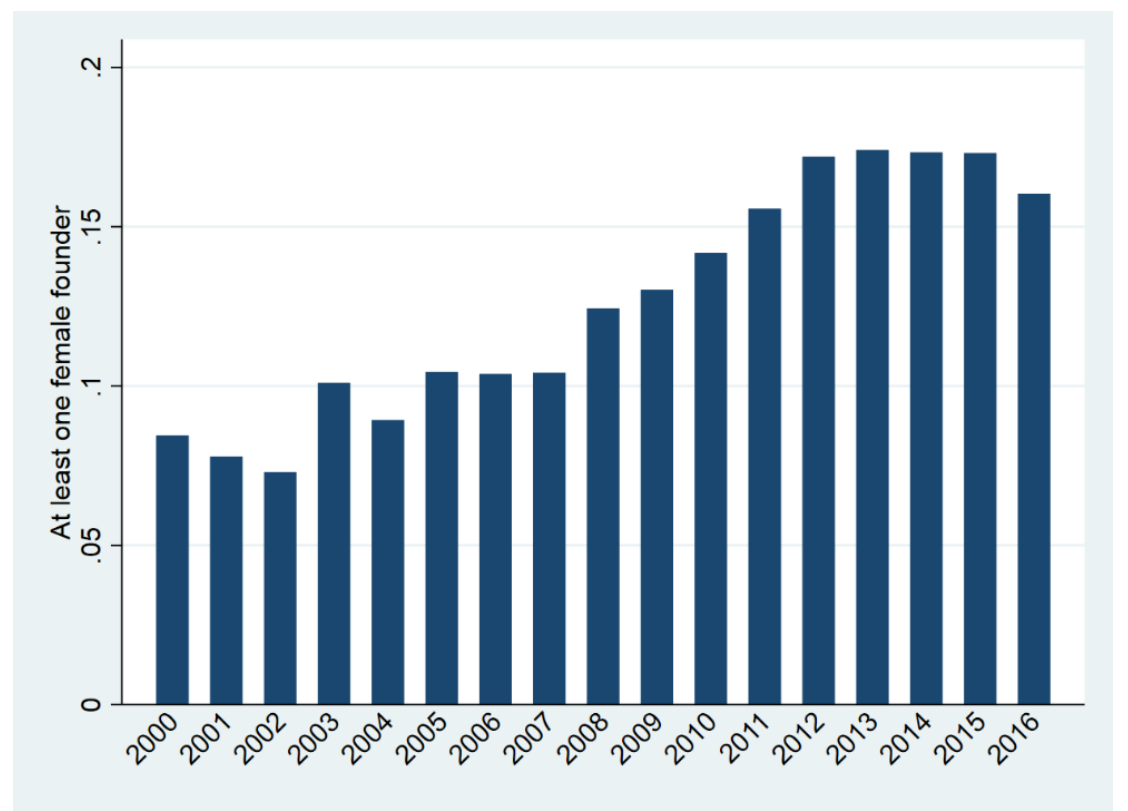

Note: The sample is limited to companies in OECD, Colombia and BRICS countries, founded between 2000 and 2017.

Source: Authors' elaborations on www.crunchbase.com 
Table 1. Differences in observable characteristics by gender

Statistics at founder level

\begin{tabular}{|c|c|c|c|}
\hline & Mean for male founders & Mean for female founders & Difference \\
\hline \multicolumn{4}{|l|}{ Founders demographics } \\
\hline Age $<25$ years old & 0.17 & 0.14 & $0.034^{\star * *}$ \\
\hline Age $>=25$ and $<=40$ years old & 0.65 & 0.70 & $-0.046^{* * *}$ \\
\hline Age $>40$ years old & 0.18 & 0.16 & 0.012 \\
\hline Had filed a patent application before founding & 0.07 & 0.04 & $0.028^{* * *}$ \\
\hline \multicolumn{4}{|l|}{ Employment variables } \\
\hline \multicolumn{4}{|l|}{ Past professional experience: } \\
\hline - CEO/Entrepreneur & 0.16 & 0.12 & $0.041^{* * *}$ \\
\hline - Leadership & 0.49 & 0.49 & -0.001 \\
\hline - Academic & 0.14 & 0.17 & $-0.033^{* * *}$ \\
\hline - Computer Scientist & 0.25 & 0.12 & $0.128^{* * *}$ \\
\hline - Finance & 0.08 & 0.07 & 0.010 \\
\hline - Engineer & 0.22 & 0.08 & $0.139^{* * *}$ \\
\hline - Business & 0.33 & 0.44 & $-0.115^{* * *}$ \\
\hline \multicolumn{4}{|l|}{ Education variables } \\
\hline Phd & 0.11 & 0.12 & -0.008 \\
\hline MBA & 0.16 & 0.17 & -0.007 \\
\hline MSc & 0.35 & 0.36 & -0.015 \\
\hline BSc & 0.81 & 0.81 & -0.001 \\
\hline \multicolumn{4}{|l|}{ Latest subject: } \\
\hline - STEM & 0.40 & 0.21 & $0.192^{* * *}$ \\
\hline$-\mathrm{IT}$ & 0.20 & 0.09 & $0.112^{\star \star \star}$ \\
\hline - Natural Sciences & 0.06 & 0.05 & 0.003 \\
\hline - Engineering & 0.14 & 0.07 & $0.078^{* * *}$ \\
\hline - Health & 0.02 & 0.03 & $-0.015^{\star \star *}$ \\
\hline - Social Sciences & 0.08 & 0.13 & $-0.053^{\star * *}$ \\
\hline - Humanities & 0.05 & 0.12 & $-0.069^{\star * *}$ \\
\hline - Business \& law & 0.33 & 0.35 & $-0.023^{*}$ \\
\hline - Education & 0.01 & 0.02 & $-0.011^{* * *}$ \\
\hline - Generics & 0.01 & 0.02 & $-0.005^{*}$ \\
\hline - Services & 0.01 & 0.01 & $-0.004^{*}$ \\
\hline
\end{tabular}

Note: The sample is limited to founders of companies in OECD, Colombia, and BRICS countries, founded between 2000 and 2017.

Source: Authors' elaborations on www.crunchbase.com

\section{The gender gap in VC financing success}

The difference in likelihood of receiving $\mathrm{VC}$ between male and female founders is rather small and not significant (Table 2). However, conditional on receiving VC, the gender gap in financing is sizeable. Female founders receive considerably less capital compared to male founders (USD 13 versus USD 9 million). Overall, the rate of successful exit for is 
$13 \%$ for start-ups with only male founders, while it is $9 \%$ for those with at least one female founder. Acquisitions and IPOs display a similar pattern between the two groups: start-ups in wich at least one founder is a woman tend to exit via acquisition one-third less often than those with male founders only. The difference in the IPO is statistically significant, however not as large as for acquisitions.

However, it is important to stress out that the exercise is purely descriptive at this stage. Other differences than gender exist between companies with male founders only and startups with at least one female founder (such as number of founders for instance) and these differences, rather than founders' gender, may be the main determinants of any revealed gap in funding or exit. Using regression analysis, the next section estimates the gender gap in funding amounts, keeping differences in observable characteristics constant.

Table 2. Differences in company characteristics for start-ups with only male founders and those with at least one female founder

Statistics at the company level

\begin{tabular}{lccc}
\hline & $\begin{array}{c}\text { Mean for start-ups with } \\
\text { only male founders }\end{array}$ & $\begin{array}{c}\text { Mean for start-ups with at } \\
\text { least one female founder }\end{array}$ & Difference \\
\hline Company has received funding & 0.54 & 0.53 & 0.010 \\
Total funding (\$m, top 1\% trimmed) & 12.66 & 8.92 & $3.733^{\star \star *}$ \\
Successful exit & 0.13 & 0.09 & $0.046^{* * *}$ \\
IPO & 0.02 & 0.01 & $0.006^{\star * *}$ \\
Acquisition & 0.12 & 0.08 & $0.042^{* * *}$ \\
Number of founders & 1.65 & 2.05 & $-0.400^{* * *}$ \\
\hline
\end{tabular}

Note: The sample is limited to founders of companies in OECD, Colombia, and BRICS countries, founded between 2000 and 2017. Total funding amounts exceeding USD 225 millions (99th percentile) are excluded to ensure that analyses are not driven by few companies receiving large deals.

Source: Authors' elaborations on www.crunchbase.com 


\section{Dissecting the gender gap - regression analyses}

The significant gender gap in venture capital financing suggests that differences in personal characteristics of male and female founders may account for a portion of the overall gender gap. For example, the widespread gender gap in STEM disciplines can be particularly relevant for innovative entrepreneurship. ${ }^{5}$ Moreover, experienced entrepreneurs are more likely to succeed in their next ventures than first-time entrepreneurs (Gompers et al., $\left.2010_{[52]}\right)$ indicating that past professional experience and the skills gained play an important role. Additional mechanisms that can contribute to the observed differences in funding may include gender differences in network formation, or other innate differences between women and men (i.e. risk preferences, aptitude for negotiation etc.). While it is impossible to control for all innate abilities and individual preferences, the analyses presented in this section make it possible to disentangle some important mechanisms - including propensity to hold a STEM degree and past professional experience - that may drive gender gap.

More specifically, this section reports results from OLS regressions of different outcomes of interest - the likelihood to receive funding, total funding amount, and successful exit on a dummy variable indicating whether the team of start-up founders includes a woman, and a rich set of control variables. Annexes A and B provide detailed summary statistics and regression results.

\section{Gender differences in financing}

In order to identify the gender gap in financing, two models are estimated. First, a linear probability model is used to investigate the probability of receiving VC funding, and second a linear model is used to estimate the amount received. The equation model for the probability of receiving $\mathrm{VC}$ is:

$$
y_{i c s t}=\alpha+\beta \text { one_woman }_{i c s t}+\gamma X_{i c s t}+\delta_{s}+\mu_{c}+\rho_{t} \quad \text { (Model 1) }
$$

for a company $i$ in country $c$, sector $s$, founded at year $t$. $y$ is the outcome of interest (a dummy indicating whether the company has received any funding), and one_woman is the variable of interest (a dummy indicating whether at least one of the founders is a woman). The control variables $X$ comprise company and founders' characteristics. In the full model, these include number of founders, their age, education level and field of education, past professional experience, and whether one founder has filed a patent application before founding the company. Control variables for founders demographics are computed at the company level and take the form of dummy variables indicating whether, "at least one founder" belongs to age cohorts, holds a $\mathrm{PhD}$, or other diplomas, has a major in natural sciences, other fields, and has past professional experience in different fields (e.g. finance).

All the specifications include country and sector fixed effects and control for the year of the start-up creation. ${ }^{6}$ Standard errors are clustered at the country-sector level. A linear probability model is a simple and straightforward choice in particular in the case when most of the independent variables are also binary (in which case the prediction is less likely to lie outside the $[0,1]$ interval) and when fixed effects are included (in order to avoid the incidental parameter problem inherent to non-linear models). However, the results are robust to the use of non-linear regression model (probit see Annex C). Results also appear robust to a number of sensitivity analysis such as considering alternative outcome variables 
(number of financing rounds), controlling for changes in the sample size, and running regressions at the founder instead of company level.

Conditional on receiving VC, a simple linear model is used to investigate the determinants of the amount of funding. The estimated model is:

$$
\log \left(y_{i c s t}\right)=\alpha+\beta \text { one_woman }_{\text {icst }}+\gamma X_{\text {icst }}+\delta_{s}+\mu_{c}+\rho_{t}
$$

It relies on the same set of explanatory variables as in Model 1. The sample in Model 2 is restricted to companies receiving at least one round of funding, and reporting the amount received.

The first column of Table 3 shows the difference in the likelihood to get funding (Model 1) and the total amount received (Model 2) between companies with only male founders and companies with at least one female founder, controlling for company characteristics. The subsequent columns show how these differences change once founders' characteristics are included.

Start-ups in which there is at least one female founder are, on average across countries and across years, 5 percentage points less likely to receive funding than start-ups founded by men only (baseline takes the probability of 0.59) (Model 1). When start-ups with one or more female founder receive funding, they also receive an amount that is $34 \%$ lower than that of male start-ups (Model 2) (Table 1, column 1). Adding incrementally founders' characteristics such as age, education level and education field, past professional experience, and patent ownership decreases the coefficient of interest in Model 1 to 3 percentage points (Table 1, Columns 2-5). This change is robust to the decrease in sample size. By contrast, in the case of the amount of funding received (conditional on receiving funding at all), including founders' characteristics as controls do not affect the difference in the amount received by male and female-founded start-ups. 
Table 3. Gender gap in funding - regression results

\begin{tabular}{|c|c|c|c|c|c|}
\hline MODEL 1 & $\begin{array}{l}\text { Probability of } \\
\text { funding }\end{array}$ & $\begin{array}{l}\text { Probability of } \\
\text { funding }\end{array}$ & $\begin{array}{l}\text { Probability of } \\
\text { funding }\end{array}$ & $\begin{array}{l}\text { Probability of } \\
\text { funding }\end{array}$ & $\begin{array}{l}\text { Probability of } \\
\text { funding }\end{array}$ \\
\hline \multirow[t]{2}{*}{$\begin{array}{l}\text { At least one } \\
\text { founder is a woman }\end{array}$} & $-0.0481^{\star * *}$ & $-0.0431^{* * \star}$ & $-0.0396^{\star \star *}$ & $-0.0348^{* \star *}$ & $-0.0322^{\star \star \star}$ \\
\hline & $(0.00719)$ & $(0.00967)$ & $(0.00949)$ & $(0.00959)$ & $(0.00946)$ \\
\hline Observations & 70,358 & 25,467 & 25,201 & 24,242 & 24,242 \\
\hline R-squared & 0.088 & 0.092 & 0.093 & 0.097 & 0.102 \\
\hline MODEL 2 & $\begin{array}{l}\text { Total funding } \\
\text { (USD, log) }\end{array}$ & $\begin{array}{l}\text { Total funding } \\
\text { (USD, log) }\end{array}$ & $\begin{array}{l}\text { Total funding } \\
\text { (USD, log) }\end{array}$ & $\begin{array}{l}\text { Total funding } \\
\text { (USD, log) }\end{array}$ & $\begin{array}{l}\text { Total funding } \\
\text { (USD, log) }\end{array}$ \\
\hline \multirow[t]{2}{*}{$\begin{array}{l}\text { At least one } \\
\text { founder is a woman }\end{array}$} & $-0.412^{\star \star *}$ & $-0.443^{\text {** }}$ & $-0.438^{\star \star *}$ & $-0.420^{\star \star *}$ & $-0.403^{\star \star *}$ \\
\hline & $(0.0452)$ & $(0.0593)$ & $(0.0570)$ & $(0.0601)$ & $(0.0610)$ \\
\hline$\%$ difference & -33.771 & -35.787 & -35.479 & -34.301 & -33.197 \\
\hline Observations & 32,078 & 13,598 & 13,466 & 12,975 & 12,975 \\
\hline R-squared & 0.262 & 0.290 & 0.293 & 0.299 & 0.310 \\
\hline Controls & $\begin{array}{r}\text { Companies' } \\
\text { characteristics }\end{array}$ & $\begin{array}{r}+ \text { age, education } \\
\text { level }\end{array}$ & + education field & $\begin{array}{r}+ \text { past } \\
\text { professional } \\
\text { experience }\end{array}$ & + patents \\
\hline
\end{tabular}

Note: Robust clustered standard errors in parentheses. $* * * \mathrm{p}<0.01, * * \mathrm{p}<0.05, * \mathrm{p}<0.1$. Regressions include the following fixed effects: country, sector, company founding year. The use of a linear probability model for binary outcome variable is justified by the fact that the independent variables are also binary (in which case the prediction is less likely to lie outside the $[0,1]$ interval) and by the presence of fixed effects (to avoid the incidental parameter problem inherent to non-linear models). Total funding amounts exceeding USD 225 millions (99th percentile) are excluded to ensure that analyses are not driven by few companies receiving large deals. Results are robust to the use of non linear regression model (probit).

Source: Authors' elaborations on www.crunchbase.com and PATSTAT data.

Disentangling the two types of female-founded start-ups - those with only female founders, and those with both male and female founders - Table B.6 in Appendix shows that the gender gap in probability to receive funding is mainly driven by start-ups with founders of both gender. Indeed, the penalty for start-ups founded by women only is eliminated by controlling for founders' characteristics but this is not the case for the penalty for start-ups with founders of both gender. ${ }^{7}$

Table B.6 also shows that the gender gap in funding amount is significant for start-ups with founders of both gender, and even stronger for companies with female founders only. The coefficients associated to both categories of start-ups are remarkably stable across specifications and in particular is not significantly reduced once founders' characteristics are included.

\section{Gender differences in exit}

Successful exit from VC financing via IPO (Initial Public Offering) or acquisition is an important milestone in the development and growth of start-ups. Because of a lack of alternative measures, these events are often used as a proxy for start-up performance (Ragozzino and Blevins, 2015[53]; Shane and Stuart, 2002 [54]; Lee and Lee, 2014[55]). 
However in Crunchbase, as in most other databases, it is not possible to distinguish between exits that provide large versus small returns on VC investment. Returns cannot be calculated for start-ups in the data because of a lack of information about the VC contracts offered to start-ups in exchange for funding. ${ }^{8}$ Furthermore, for acquisitions, acquisition price is usually not disclosed publicly and for IPOs, information on money raised is also missing in most of the cases.

IPO and acquisitions are very different exit outcomes for start-up founders. After an acquisition, when the venture is sold to a third party, founders usually leave the company. ${ }^{9}$ On the contrary, after an IPOs, the entrepreneur usually remains involved. Brau, Francis and Kohers $\left(2003_{[56]}\right)$ show that the choice between these two types of restructuring is mainly driven by industry characteristics (concentration, return on investment, sector), financial markets specificities (cost of debt, state of the IPO market), firms characteristics (firm size, insider ownership percentage) as well as deal-specific factors. While in China and India, IPOs represent the vast majority of exits for VC-backed companies, in the United States, Europe and Israel, the exit strategy for VC-backed companies is acquisitions (representing more than $90 \%$ of all exits) (Ernst \& Young (EY), 2012 ${ }_{[57]}$ ).

A linear probability model is employed to investigate the importance of gender for exit:

$$
y_{i c s t}=\alpha+\beta \text { one_woman } i c s t+\gamma X_{i c s t}+\delta_{s}+\mu_{c}+\rho_{t} \quad \text { (Model 3) }
$$

for a company $\mathrm{i}$ in country c, sector s, founded at year t. $y$ is the outcome of interest (a dummy indicating a successful exit via IPO or acquisition) and one_woman is the variable of interest (a dummy indicating whether at least one of the founders is a woman). The control variables X comprise company and founders' characteristics. In the full model, these include number of founders, their age, education level and major, past professional experience, and whether one founder has filed a patent application before company founding the company. It also includes information on funding such as year of first funding received, total funding amount, number of funding rounds. All the specifications include country and sector fixed effects and control for the year of start-up creation. ${ }^{10}$ Standard errors are clustered at the country-sector level.

Table 4 shows differences between female-led and male-only enterprises in terms of the probability to experience a successful exit. The analyses consider two possible exit events: acquisitions and IPOs (Initial Public Offerings). Regarding the probability of acquisition, there remains a negative difference between both types of start-ups: companies with at least one female founder are less likely to be acquired by 2-3 percentage point (out of a baseline probability of 0.13 ). This difference increases when founders' characteristics are controlled for; however this effect is due to the reduction in sample size so that the result cannot be interpreted. Columns 1 and 2 show that the difference between gender in likelihood to go public is small and not significant. This is true both conditional on companies' characteristics only (such as amount of funding received, sector, number of founders, column 1), and conditional on companies' and founders' characteristics (column 2 - for the full list of control variables, see Table B.3 in Appendix).

The difference in likelihood of acquisition between male and female-founded companies may be the sign of a lower success and performance of start-ups founded by women. It may also reflect the adoption of different exit strategies by both types of founders. It is possible that female founders prefer to keep control of the company and continue to grow their business independently (Kanze et al., 2018 $8_{[18]}$ ). Indeed, companies with a solid business model and sufficient scale might choose to reinvest the profits in the company, and part of the profits can be distributed to investors as a dividend. In order to better understand the 
difference in successful exit between the male and female-founded start-ups, it would be interesting to consider alternative measures of start-up performance that go beyond exit via IPO and acquisition. Other indicators could include revenue or employment growth for instance. However, these data are not readily available in Crunchbase and particular effort should be undertaken to build such variables, possibly exploiting information contained in companies' websites.

Table 4. Gender gap in exit - regression results

\begin{tabular}{|c|c|c|c|c|}
\hline & IPO & IPO & Acquisition & Acquisition \\
\hline \multirow[t]{2}{*}{$\begin{array}{l}\text { At least one founder is a } \\
\text { woman }\end{array}$} & 0.00174 & 0.00139 & $-0.0205^{\star \star *}$ & $-0.0327^{\star \star *}$ \\
\hline & $(0.00248)$ & $(0.00301)$ & $(0.00547)$ & $(0.00843)$ \\
\hline Observations & 27,310 & 10,888 & 31,522 & 12,785 \\
\hline R-squared & 0.124 & 0.154 & 0.169 & 0.172 \\
\hline Controls & $\begin{array}{r}\text { Companies' } \\
\text { characteristics }\end{array}$ & $\begin{array}{r}\text { Companies' and } \\
\text { founders' } \\
\text { characteristics }\end{array}$ & $\begin{array}{r}\text { Companies' } \\
\text { characteristics }\end{array}$ & $\begin{array}{r}\text { Companies' and } \\
\text { founders' } \\
\text { characteristics }\end{array}$ \\
\hline
\end{tabular}

Note: Robust clustered standard errors in parentheses. $* * * \mathrm{p}<0.01, * * \mathrm{p}<0.05, * \mathrm{p}<0.1$. Regressions include the following fixed effects: country, sector, company founding year, funding category.

Source: Authors' elaborations on www.crunchbase.com

Table B.7 in Appendix shows that the gender gap in acquisition is somewhat similar for female only start-ups and for start-ups with male and female founders. It also confirms that there is no gender gap in the likelihood to become public via IPOs even after disentangling between the two types of female founded start-ups.

\section{The gender gap illustrated}

To put the results presented above in perspective, this subsection shows how the average adjusted predictions for different outcomes of interest (funding probability and amount, and likelihood of successful exit) differ between the two types of start-ups: those with at least one female founder versus those founded by men only. ${ }^{11}$ This is done for the restricted sample of companies with a full list of founders' characteristics.

In the sample, the average male founded company has a $63 \%$ chance of receiving funding while an otherwise-comparable company with at least one female founder has a $60 \%$ chance (Figure 9, top left panel). Male founded companies receive USD 13.6 million on average, while those with one or more women in the team of founders receive USD 10 million, all else being equal (Figure 9, top right panel). Both types of companies have a low probability to become public via an IPO (Figure 9, bottom left panel). If anything, female founded companies, i.e. start-ups with at least one female founder, appear more successful in that respect; however the difference is not statistically significant. The probability of acquisition is equal to $14 \%$ on average for female founded companies, and $17 \%$ for companies founded by men only (Figure 9, bottom right panel). Contrary to IPOs, the difference is large and significant. 
Figure 9. Differences in funding and exit between male-founded companies and those with at least one female founder is a woman

Predicted probabilities (values in the case of funding amount)
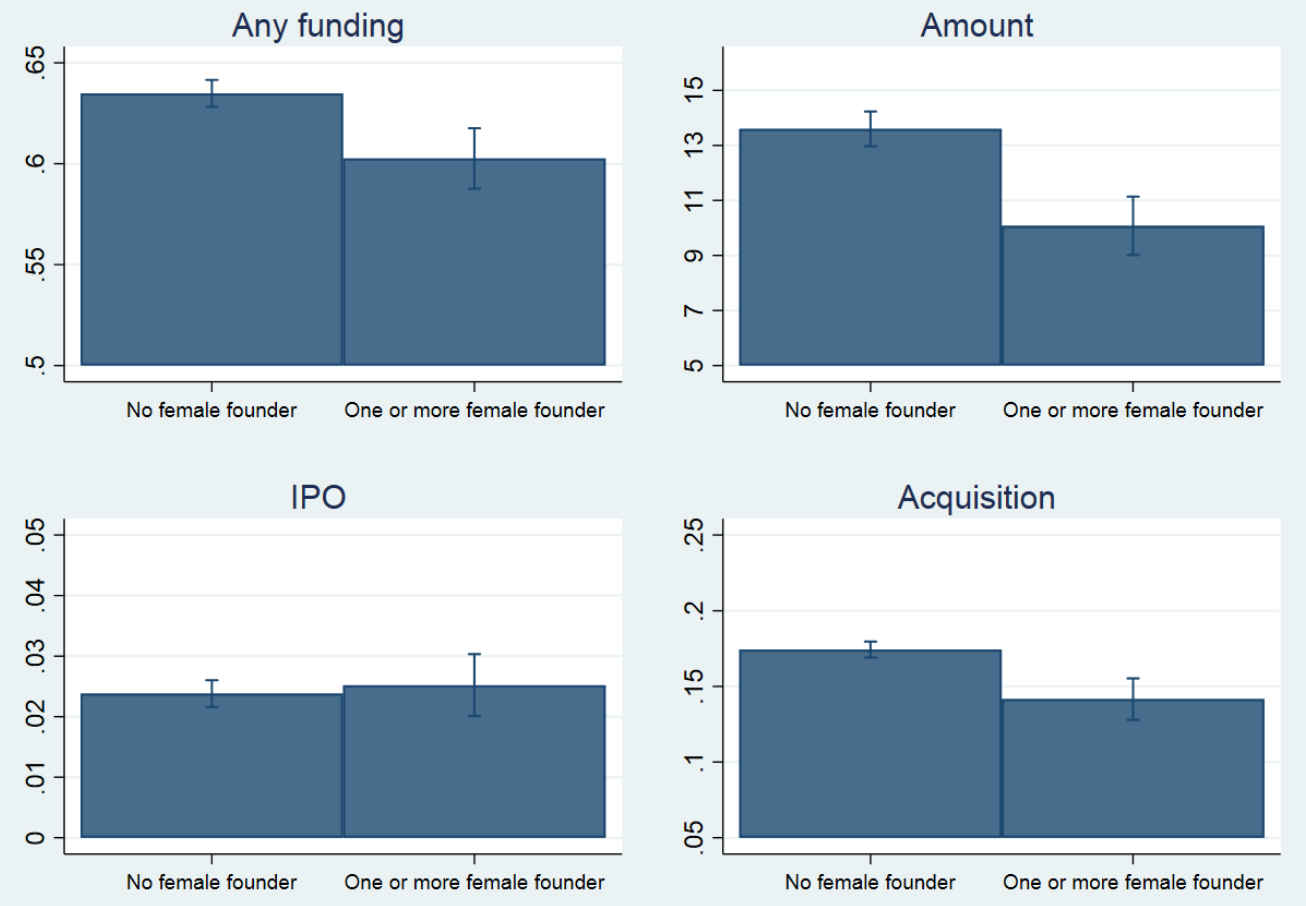

Note: The sample is restricted to companies located in OECD, Colombia, and BRICS countries, created after 2000, and for which founders' demographic variables are not missing. The graphs show adjusted predictions based on regressions presented above (Full specification). For funding amount, predictions are based on negative binomial regressions. This is to accommodate the variable's skewness and over dispersion without the use of a log-linear model that would overly complicate the computation of adjusted predictions. Total funding amounts exceeding USD 225 millions (99th percentile) are excluded to ensure that analyses are not driven by few companies receiving large deals. Whisker lines report 95\% confidence intervals.

Source: Authors' elaborations on www.crunchbase.com and PATSTAT data.

The gender gap in start-up funding and successful exit varies across three different regions of the world where the venture capital market has reached a different degree of maturity: the United States, Europe, and Asia (Figure 10 and Table B.4 and B.5). Differences between gender in the probability to get any funding is mostly present in Europe where companies with at least one female founder are close to 6 percentage points less likely to get funding even when controlling for companies and founders' characteristics. In the United States the difference is smaller and only marginally significant while in Asia no difference is found. Indeed in the United States and in Europe, the average probability for male founded companies to receive any funding is equal to $65 \%$. However, in the United States the gender gap is slightly less pronounced: female founded companies are $62 \%$ likely to get funding while in Europe they are less than $60 \%$. Both male and female founded companies in Asia have a lower probability to get funding (around 56\%) and the difference between both types is not significant.

On the contrary, the largest gap in the funding amount is found in the United States, where female founded companies receive amounts lower by a third compared to male founded 
companies. In Europe this figure is similar, but the gap is not significant in Asia. However, female founded companies in the United States still receive larger amounts than male founded companies in Europe.

In terms of successful exit, the difference between gender in probability to go public via an IPO is not significant in the three regions. For both types of companies, this exit strategy is less likely in Europe than in the United States or Asia. The gender gap in acquisition is driven by the market in the United States, where on average companies with male founders only have a $22 \%$ chance to be acquired, while this figure is equal to $18 \%$ for start-ups with at least one female founder. The acquisition market is less developed in Europe and Asia, where companies are on average only less than $12 \%$ likely to be acquired, with no significant difference between both types of companies.

Results for start-ups located in Canada (not reported in the Figures) suggest that the gender gap faced by female-founded start-ups in Canada is similar than in the United States: while the gap in probability to get funding is not as large as in Europe (not statistically different from zero), the total amount received by female-founded companies is much lower than for male-only founders and can be up to $45 \%$. 
Figure 10. Differences in funding and exit male-founded companies and those in which at least one founder is a woman across countries

Predicted probabilities (values in the case of funding amount)
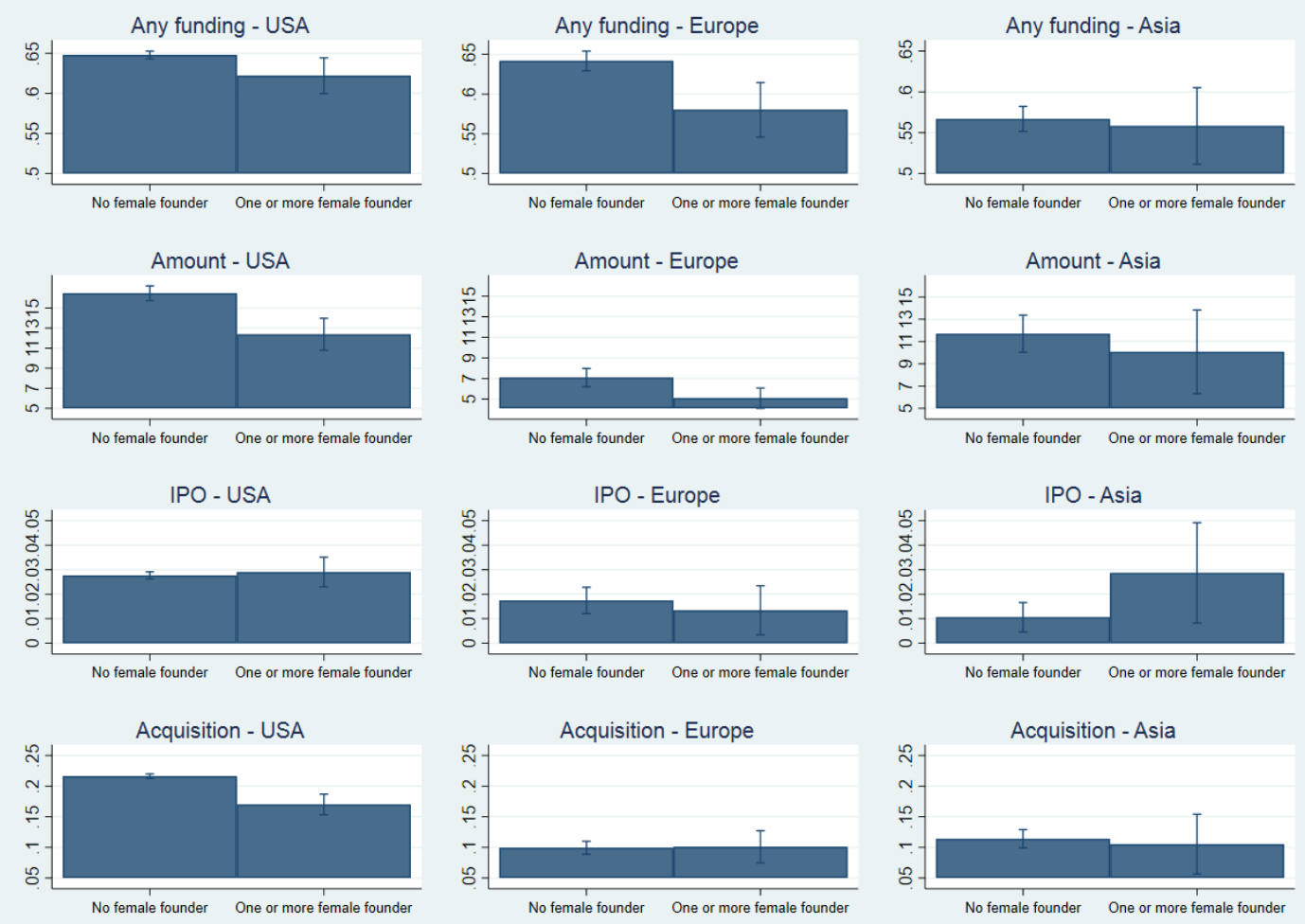

Note: The sample is restricted to companies located in OECD, Colombia and BRICS countries, created after 2000 , and for which founders' demographic variables are not missing. The graphs show adjusted predictions based on regressions presented in section 2.1 and 2.2. For funding amount, predictions are based on negative binomial regressions. This is to accommodate the variable's skewness and over dispersion without the use of a log-linear model that would overly complicate the computation of adjusted predictions. Total funding amounts exceeding USD 225 millions (99th percentile) are excluded to ensure that analyses are not driven by few companies receiving large deals. Whisker lines report 95\% confidence intervals. Country groupings are described in Table A.1.

Source: Authors' elaborations on www.crunchbase.com and PATSTAT data.

Figure 11 shows how the significance of the gender gap in funding and exit varies for different types of founders. In particular, the gender gap in the probability of funding is no longer significant in the case of companies with founders holding a STEM degree, founders with patents, and founders that have previous experience as CEO (experienced entrepreneurs) (top left panel). In terms of amount of funding, there is still a significant gap for companies with founders with STEM degrees, but not for patent holders or founders with experience as CEOs. The picture is very similar for the probability of acquisition. 
Figure 11. Gender gaps in funding and exit between male-founded companies and those for which at least one founder is a woman for different categories of founders

Negative gap means female founders are less likely to receive funding, exit or receive lower funding amounts
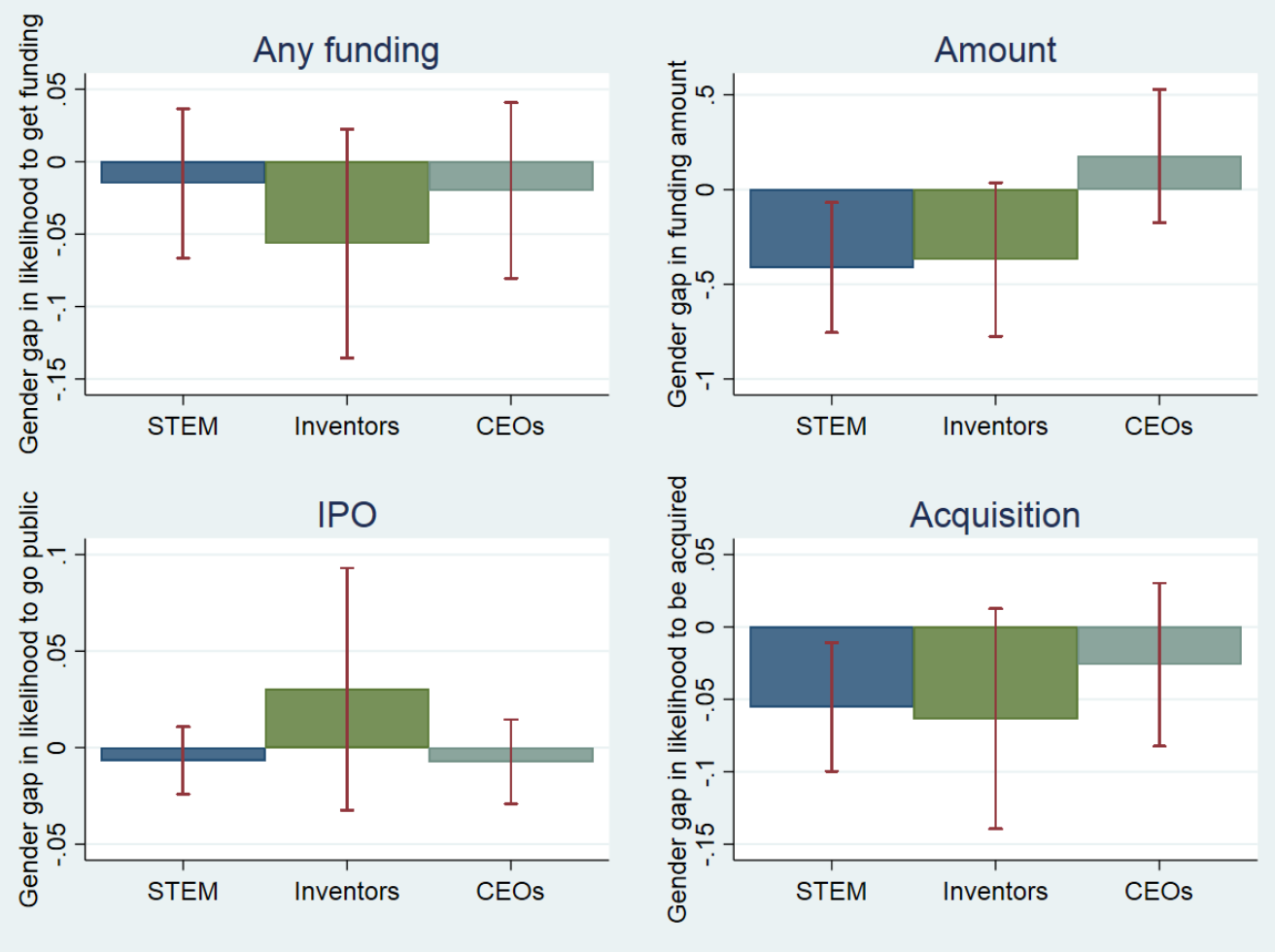

Note: The sample is restricted to companies located in OECD, Colombia and BRICS countries, created after 2000, and for which founders' demographic variables are not missing. Total funding amounts exceeding USD 225 millions (99th percentile) are excluded to ensure that analyses are not driven by few companies receiving large deals. Whisker lines report $95 \%$ confidence intervals.

Source: Authors' elaborations on www.crunchbase.com and PATSTAT data. 


\section{Policy implications and ideas for further work}

There is a large gender gap in the creation of innovative start-ups. There is also a significant, though smaller, gender gap in the venture capital funding of innovative startups. This study finds that start-ups with at least one woman in the team of founders are less likely to receive funding by $10 \%$ compared to start-ups founded by men only. The gap is notably lower once controlling for founders' characteristics, suggesting that part of the gender gap is due to the fact that women founders exhibit features, such as education and past job profiles that are negatively correlated with funding success. This is further confirmed by the finding that for companies with founders with STEM degrees or CEO experience, the gap is eliminated. On the other hand, if funding is successful, the gap in the amount of funding is stable even when controlling for individual characteristics. Only female founders with past CEO experience see no gap in amounts relative to men.

Fostering entrepreneurship is a key policy goal for governments of all OECD countries, which share the expectation that high rates of entrepreneurial activity will bring sustained job creation and boost the development and adoption of new products, processes, and organisational innovation. Addressing general policy failures and some of the specific bottlenecks in access to finance could potentially remove barriers to innovative entrepreneurship, and by extension to female entrepreneurship. Governments have aimed to reform framework conditions such as tax policy and labour market regulations in order to encourage reallocation of financing towards potentially high-growth firms (OECD, $2019_{[58]}$. More specific measures aiming at improving access to finance include publicprivate microfinance schemes, credit loan guarantee schemes, and public-private venture capital.

However, crafting more targeted policies aimed specifically at female entrepreneurship requires a thorough understanding of the channels through which the gender gap emerges. It is important to distinguish between entrepreneur-driven and investor-driven channels. With respect to entrepreneur-driven channels, effective policy interventions may have only an indirect relationship with entrepreneurship policy per se. For example, higher levels of female entrepreneurship have been found related to greater provision of child care services, reflecting the pervasive unequal gender balance of household responsibilities. ${ }^{12}$ Improving child care services can hence result in incidental benefits on female entrepreneurship, even if this is not their underlying policy motivation.

Similarly, the analysis suggests that founders' education and work experience tend to be associated with the likelihood of obtaining funding. Specifically, women founders tend to be less well equipped in terms of education and professional background, once controlling for the sector of start-up activity. In that sense, part of the gender gap can hence be attributed to a gender gap in education and fields of interest and careers (e.g. STEM). Policy to close the funding gender gap would need to address upstream factors related to education and training. Greater female entrepreneurship would be an incidental benefit arising out of policy interventions which are motivated by broader objectives associated with education policy. Moreover, some existing policies may seek to address this issue directly. Examples include the emphasis placed on encouraging women's participation in STEM entrepreneurship in the last decade or through various Business Supporting Programs (see Council of Economic Advisers, 2015). 
On the investor side, investors make their funding decisions based on available information and their conscious or unconscious interpretation of this information. In the presence of asymmetric information there may be market inefficiencies. Specifically, the gender of the founder may - rightly or wrongly - be perceived to be associated with the probability and extent of future success, and hence their expected returns. Even once individual characteristics are controlled for, gender of founders remains in particular a significant explanatory factor for the amount of funding received.

However, this study is not in the position to identify outright gender discrimination. First, a number of gender differences may be difficult to pick up in readily available data. For example, while Crunchbase provides data on the success and amount of funding, there is no means of evaluating how these relate to the amounts requested. In other words, if women founders ask for less funding, this could be a reason why they receive less funding. This may be the case as studies find that women exhibit different attitudes toward negotiation (Exley, forthcoming $\left.{ }_{[40]}\right)$. This may indicate that they might be looking for funding in a less effective way, ask for lower amounts, or that they may poorly negotiate the funding deal. Sociological literature also provides examples of gender differences in risk attitudes (Eckel and Grossman, 2002 $2_{[36]}$; Dohmen et al., 2011 ${ }_{[37]}$ ) and competition (Buser, Niederle and Oosterbeek, 2014 ${ }_{[39]}$; Croson and Gneezy, 2009 [59]) that could explain differences in VC funding. The perceived lack of fit makes women less likely to pursue roles such as that of a high-growth, high-potential entrepreneur. Well-designed policy interventions can play a role in overcoming such obstacles. However, this is an area which requires further analysis in order to assess policy implications.

It is also possible that the observed gender gap in start-up financing is a reflection of the underlying objectives of male and female entrepreneurs. Women tend to be associated with less capital-intensive businesses and less aggressive growth efforts (Kanze et al., 2018 ${ }_{[18]}$ ). Furthermore, female founders may be more likely to have a desire to keep control of the company and continue to grow their business independently. This argument seems plausible given that in general female and male entrepreneurs declare having different motivations than men to start a business (Figure 2). The validation or rejection of this hypothesis bears important policy implications. Indeed, if male and female founders have different objective functions, targeted policy interventions are unlikely to be welfaremaximising.

This study already provides some tentative insights for the different channels laid out above. Firstly, controlling for sector, education and work experience reduced the gender gap for the probability of financing, but not for the amount - which would be consistent with the "ask for less" hypothesis. Secondly, women with very specific qualifications - like being a $\mathrm{CEO}$ in the past - do not seem penalised in the funding market.

Nevertheless, women with identical qualifications and aspirations as men may be discriminated in the VC market if investors assume that they will not be as successful in running the business. Unfortunately, the Crunchbase dataset does not allow for measurement of the aspirations of the founders, nor the quality of the actual business proposal. However, one aspect of discrimination that can be addressed in future work is homophily - a tendency of people to trust, prefer or favour those who resemble themselves. In this respect, male VC fund investors may have a preference to entrust male funders with their investment. Notably, VC finance is dominated by men. For example, $74 \%$ and $86 \%$ of VC funds in the United States and Canada respectively do not have a female partner and two-thirds of Canadian venture capital is in funds with no women in senior roles. ${ }^{13}$ If gender-homophily is an issue, policy responses could help mitigate some of it. For example, 
government-backed VC funds could target women-led start-ups or have gender quotas for their own top staff. The efficiency of such interventions need to be evaluated closely, so that the funds are put to their best use.

More generally, none of the underlying gender differences affecting VC funding success or their perceptions by investors - are necessarily fixed. Understanding the magnitude of the phenomenon, and to what extent it constitutes a problem, can help to craft policies to address them. On the one hand, promotion of role models or success stories may be effective "soft policies" that have far reaching implications, including the perceptions of success and hence the decision to found an innovative start-up and apply for VCs. On the other hand, the share of female led start-ups searching for VC funding is particularly low in countries not commonly perceived as discriminating against women or lacking role models, such as the Nordic countries. This may indicate that personal choice and the availability of (job market or lifestyle) alternatives may play an important role in the decision to apply for $\mathrm{VC}$ financing. The ultimate objective would be to lift policy related barriers or discriminatory social norms that discourage women from embarking on risky business strategies.

Many countries already have instruments to support the funding of innovative female entrepreneurs, some of them being widely considered as successful, in particular public investment schemes (see Box 1. for an example). Thorough collection and monitoring of relevant policy settings - including, but not restricted to, public investment schemes would be a milestone in assessing their effects and cost-effectiveness. Subsequent empirical analysis of the effects of these policy settings could help to form views on what constitutes best practice in an area where policy options are often still in the phase of experiment and cross-country experience lacking. See, for example, (OECD, 2018 $[60])$.

This paper has shed light on the gender gap in high-potential start-up funding. Still, a significant part of this gap remains unexplained, particularly in terms of funding amounts. Moreover, the case for - and the form of - specific policy interventions remains an open question. While the current dataset and analysis provides some preliminary insights, extensions proposed below could push the understanding of the drivers of the gender gap further, allowing for more precise insights on the desirability and choice of the policy intervention.

Potential further work proposed:

- The collection of data on policies targeting gender equality in innovative entrepreneurship and mapping into Crunchbase data on start-ups. The objective would be to use empirical work to shed light on whether these policies correctly identify the problem and address it in an efficient way.

- The investigation of homophily. Using investor characteristics can further deepen the understanding whether in the presence of asymmetric information and risks investors tend to discriminate in favour of those who resemble them, e.g. those of the same gender. A different angle of homophily could be addressed by looking at who teams with whom, as some $40 \%$ of the companies in the sample count more than two founders.

- A follow-up survey to assess personal traits and preferences, in particular on the amounts and conditions of funding relative to expectations or requests and on underlying motivations. Such a survey would need to be conducted in collaboration with the data supplier, but would allow to confirm or eliminate the hypothesis of gender discrimination in the funding amount. 
- Scholars have also pointed to gender differences in network formation and to the importance of social network ties to secure VC funding (Stephan and El-Ganainy, $\left.2007_{[61]}\right)$. Networking is a different dimension to observe and to measure. Information retrievable from participations to start-up events and activity in the social networks (e.g. Twitter) or co-authorship of patents or academic research articles can be used to build plausible proxies of individuals' networks.

\section{Box 1. Example of public VC fund with a targeted gender programme: Start-Up Chile}

Taking exit through acquisition as a measure of success, almost all of the top 10 successful start-up accelerators around the world are private. The exception is Start-Up Chile (SUC). which was launched in 2010 by the Chilean government (Forbes, 2018). ${ }^{1}$ SUC is currently regarded one of the most successful government-led start-up accelerator programme in the world with an overall survival rate of $54.5 \%$. In contrast to many government-led funds it is open to start-ups from other countries. Moreover, SUC has a longer term focus, with goals not tied solely to valuations, but a focus on creating an entrepreneurial ecosystem. Interestingly, it includes a special programme for female-founders. There are three distinct programmes of SUC:

- S Factory is a pre-acceleration programme for start-ups in early concept stage for female founders from all around the world. Selected start-ups receive around USD 14000 equity free and 4 months acceleration (i.e. seed investment, connections, mentorship, educational components) that culminate in a public pitch event. After the 4 months, successful start-ups may apply for the seed programme. There are two application rounds per year selecting 20-30 high potential female founded start-ups in each round. Instead of establishing a gender quota for the accelerator, SUC decided that a supported programme for less experienced female entrepreneurs would have a stronger impact on changing the low-female-founded start-up ratio.

- Seed is an acceleration programme for start-ups with a functional product and early validation. Selected companies receive around USD 30000 equity free and 6 months acceleration. There are two rounds per year selecting 80-100 companies in each round.

- Scale is the final programme funding top performing start-ups. Selected companies must have passed through the Start-Up Chile seed programme initially. They receive around USD 86000 equity free. There are two rounds per year of 20-30 companies in each round.

1. $\quad$ https://www.forbes.com/sites/jonathanmoed/2018/11/19/start-up-chiles-impact-2010-2018-inside-therevolutionary-startup-accelerator/\#325e8a196dc5 Accessed on 30.01.2019. 


\section{References}

Alesina, A., F. Lotti and P. Mistrulli (2013), "Do Women Pay More For Credit? Evidence from Italy", Journal of the European Economic Association, Vol. 11/1, pp. 45-66, http://dx.doi.org/10.1111/j.1542-4774.2012.01100.x.

Alexy, O. et al. (2011), "Social capital of venture capitalists and start-up funding", Small

Business Economics, Vol. 39/4, pp. 835-851, http://dx.doi.org/10.1007/s11187-011-9337-4.

Amit, R., E. Muller and I. Cockburn (1995), "Opportunity costs and entrepreneurial activity", Journal of Business Venturing, Vol. 10/2, pp. 95-106, http://dx.doi.org/10.1016/08839026(94)00017-O.

Balachandra, L. et al. (2017), “Don’t Pitch Like a Girl!: How Gender Stereotypes Influence Investor Decisions", Entrepreneurship Theory and Practice, Vol. 43/1, pp. 116-137, http://dx.doi.org/10.1177/1042258717728028.

Barber, B. (2001), "Boys Will be Boys: Gender, Overconfidence, and Common Stock Investment", The Quarterly Journal of Economics.

Baumol, W. (1990), "Entrepreneurship: Productive, Unproductive, and Destructive", Journal of Political Economy, Vol. 98/5, pp. 893-921, http://dx.doi.org/10.1086/261712.

Becker-Blease, J. and J. Sohl (2007), "Do women-owned businesses have equal access to angel capital?", Journal of Business Venturing, Vol. 22/4, pp. 503-521, https://econpapers.repec.org/article/eeejbvent/v_3a22_3ay_3a2007_3ai_3a4_3ap_3a503521.htm.

Becker, G. (1957), The Economics of Discrimination, The University of Chicago Press, Chicago \& London.

Bell, A. et al. (2017), Who Becomes an Inventor in America? The Importance of Exposure to Innovation, National Bureau of Economic Research, Cambridge, MA, http://dx.doi.org/10.3386/w24062.

Bellucci, A., A. Borisov and A. Zazzaro (2010), "Does gender matter in bank-firm relationships? Evidence from small business lending", Journal of Banking \& Finance, Vol. 34/12, pp. 2968-2984, http://dx.doi.org/10.1016/J.JBANKFIN.2010.07.008.

Bender, S. et al. (2018), "Management Practices, Workforce Selection, and Productivity", Journal of Labor Economics, Vol. 36/S1, pp. S371-S409, http://dx.doi.org/10.1086/694107.

Bertoni, F. and T. Tykvová (2015), "Does governmental venture capital spur invention and [49] innovation? Evidence from young European biotech companies", Research Policy, Vol. 44/4, pp. 925-935, http://dx.doi.org/10.1016/j.respol.2015.02.002. 
Bigelow, L. et al. (2014), "Skirting the Issues: Experimental Evidence of Gender Bias in IPO Prospectus Evaluations", Journal of Mangement, Vol. 40/6, pp. 1732-1759, http://dx.doi.org/10.1177/0149206312441624.

Block, J., G. De Vries and P. Sandner (2012), Venture Capital and the Financial Crisis: An Empirical Study across Industries and Countries, Oxford University Press, http://dx.doi.org/10.1093/oxfordhb/9780195391596.013.0003.

Brau, J., B. Francis and N. Kohers (2003), "The Choice of IPO versus Takeover: Empirical Evidence*”, The Journal of Business, Vol. 76/4, pp. 583-612, http://dx.doi.org/10.1086/377032.

Breschi, S. (2017), "Knowledge and Social Defences: The Effect on Knowledge and Social Interdependencies on Inventor Outward Mobility".

Breschi, S. et al. (forthcoming), Never walk alone? A cross-country analysis of governments venture capital investments.

Breschi, S., J. Lassébie and C. Menon (2018), "A portrait of innovative start-ups across countries", OECD Science, Technology and Industry Working Papers, No. 2018/2, OECD Publishing, Paris, http://dx.doi.org/10.1787/f9ff02f4-en.

Brooks, A. et al. (2014), "Investors prefer entrepreneurial ventures pitched by attractive men", Proceedings of the National Academy of Sciences, Vol. 111/12, pp. 4427-4431, http://dx.doi.org/10.1073/pnas.1321202111.

Brush, C. et al. (2014), Diana Report Women Entrepreneurs 2014: Bridging the Gender Gap in Venture Capital, http://www.babson.edu/Academics/centers/cwel/thoughtleadership/diana/Documents/diana-project-executive-summary-2014.pdf.

Buser, T., M. Niederle and H. Oosterbeek (2014), "Gender, Competitiveness, and Career Choices *", The Quarterly Journal of Economics, Vol. 129/3, pp. 1409-1447, http://dx.doi.org/10.1093/qje/qju009.

Calvino, F., C. Criscuolo and C. Menon (2015), "Cross-Country Evidence on Start-up Dynamics", OECD Science, Technology and Industry Working Papers, http://dx.doi.org/10.1787/5jrxtkb9mxtb-en.

Clark, C. (2008), “The impact of entrepreneurs' oral 'pitch' presentation skills on business angels' initial screening investment decisions", Venture Capital, Vol. 10/3, pp. 257-279, http://dx.doi.org/10.1080/13691060802151945.

Coleman, S. and A. Robb (2009), "A comparison of new firm financing by gender: evidence from the Kauffman Firm Survey data", Small Business Economics, Vol. 33/4, pp. 397-411, http://dx.doi.org/10.1007/s11187-009-9205-7.

Council of Economic Advisers (2015), Expanding Opportunities for Women in Business, https://obamawhitehouse.archives.gov/sites/default/files/docs/women_in_business_issue_brie f_final_nonembargoed.pdf (accessed on 27 September 2018). 
Criscuolo, C., P. Gal and C. Menon (2014), "The Dynamics of Employment Growth: New Evidence from 18 Countries", No. Criscuolo et al., 2014, CEP Discussion Paper No 1274, http://cep.lse.ac.uk/pubs/download/dp1274.pdf.

Croson, R. and U. Gneezy (2009), "Gender Differences in Preferences", Journal of Economic Literature, Vol. 47/2, pp. 448-474, http://dx.doi.org/10.1257/jel.47.2.448.

Dalle, J., M. den Besten and C. Menon (2017), "Using Crunchbase for economic and managerial research", OECD Science, Technology and Industry Working Papers, No. 2017/08, OECD Publishing, Paris, https://dx.doi.org/10.1787/6c418d60-en.

Dezső, C. and D. Gaddis Ross (2012), "Does Female Representation in Top Management Improve Firm Performance? A Panel Data Investigation", Strategic Management Journal, Vol. 33/9, pp. 1072-1089, http://ssrn.com/abstract=1088182.

Dohmen, T. et al. (2011), "Individual Risk Attitudes: Measurement, Determinants, and Behavioral Consequences", Journal of the European Economic Association, Vol. 9/3, pp. 522-550.

Eckel, C. and P. Grossman (2002), "Sex differences and statistical stereotyping in attitudes toward financial risk", Evolution and Human Behavior, Vol. 23/4, pp. 281-295, http://dx.doi.org/10.1016/s1090-5138(02)00097-1.

Eddleston, K. et al. (2016), "Do You See What I See? Signaling Effects of Gender and Firm Characteristics on Financing Entrepreneurial Ventures", Entrepreneurship Theory and Practice, Vol. 40/3, pp. 489-514, http://dx.doi.org/10.1111/etap.12117.

Ernst \& Young (EY) (2018), Research Reveals Boys' Interest in STEM Careers Declining; Girls' Interest Unchanged, https://www.ey.com/us/en/newsroom/news-releases/news-eyresearch-reveals-boys-interest-in-stem-careers-declining-girls-interest-unchanged (accessed on December 2018).

Ernst \& Young (EY) (2012), Globalizing Venture Capital: Global venture capital insights and trends report, https://www.ey.com/Publication/vwLUAssets/Globalizing_venture_capital_VC_insights_and trends_report_CY0227/\$FILE/Globalizing\%20venture\%20capital_VC\%20insights\%20and \%20trends\%20report_CY0227.pdf (accessed on January 2019).

Ewens, M. (forthcoming), “Are Early Stage Investors Biased Against Women?”, Journal of Financial Economics.

Exley, C. (forthcoming), "Knowing When to Ask: The Cost of Leaning-in”, Journal of Political Economy.

Fried, V. and R. Hisrich (2018), "Toward a Model of Venture Capital Investment Decision Making”, Financial Management, Vol. 23/3, pp. 28-37, https://www.jstor.org/stable/pdf/3665619.pdf?refreqid=excelsior\%3Ad21d943e7e6656eab54 675298f4ae1b4. 
Gompers, P. et al. (2010), "Performance persistence in entrepreneurship", Journal of Financial Economics, Vol. 96/1, pp. 18-32, http://dx.doi.org/10.1016/j.jfineco.2009.11.001.

Gompers, P. and S. Wang (2017), “And the Children Shall Lead: Gender Diversity and Performance in Venture Capital", No. 23454, National Bureau of Economic Research, http://dx.doi.org/10.3386/w23454.

Gompers, P. and S. Wang (2017), "Diversity in Innovation”, No. 23082, National Bureau of Economic Research, http://dx.doi.org/10.3386/w23082.

Gornall, W. and I. Strebulaev (2015), "The Economic Impact of Venture Capital: Evidence from Public Companies”, SSRN Electronic Journal, http://dx.doi.org/10.2139/ssrn.2681841.

Grünfeld, L. et al. (2019), Female Entrepreneurship in Norway: Development Features, Barriers, and Opportunities, Menon Economics.

Haltiwanger, J. (2012), "Job Creation and Firm Dynamics in the United States", Innovation Policy and the Economy, Vol. 12/1, pp. 17-38, http://dx.doi.org/10.1086/663154.

Haltiwanger, J., R. Jarmin and J. Miranda (2013), "Who Creates Jobs? Small versus Large versus Young", Review of Economics and Statistics, Vol. 95/2, pp. 347-361, http://dx.doi.org/10.1162/REST a 00288.

Hebert, C. (2018), Mind the Gap: Gender Stereotypes and Entrepreneur Financing.

Inzlicht, M. and T. Schmader (2011), Stereotype Threat: Theory, Process, and Application, Oxford University Press, http://dx.doi.org/10.1093/acprof:oso/9780199732449.001.0001.

Kanze, D. et al. (2018), "We Ask Men to Win and Women Not to Lose: Closing the Gender Gap in Startup Funding", Academy of Management Journal, Vol. 61/2, pp. 586-614, http://dx.doi.org/10.5465/amj.2016.1215.

Kaplan, S. and P. Stromberg (2003), "Financial Contracting Theory Meets the Real World: An Empirical Analysis of Venture Capital Contracts", Review of Economic Studies, Vol. 70/2, pp. 281-315, http://dx.doi.org/10.1111/1467-937X.00245.

Lawless, J. and R. Fox (2013), Girls Just Wanna Not Run, https://www.american.edu/spa/wpi/upload/Girls-Just-Wanna-Not-Run_Policy-Report.pdf.

Lee, S. and B. Lee (2014), "Entrepreneur characteristics and the success of venture exit: an analysis of single-founder start-ups in the U.S.", International Entrepreneurship and Management Journal, Vol. 11/4, pp. 891-905, http://dx.doi.org/10.1007/s11365-014-0324-5.

Marlino, D. and F. Wilson (2002), Teen Girls on Business: Are they Being Empowered?, Simmons School of Mangement, https://www.ncgs.org/wp-content/uploads/2017/11/TeenGirls-on-Business-Are-They-Being-Empowered.pdf.

OECD (2019), Going for Growth, forthcoming. 
OECD (2018), "Entrepreneurship at a Glance", https://www.oecd.org/sdd/business-stats/EAG2018-Highlights.pdf.

OECD (2017), Entrepreneurship at a Glance 2017, OECD Publishing, Paris, https://dx.doi.org/10.1787/entrepreneur_aag-2017-en.

OECD (2016), PISA 2015 Results (Volume I): Excellence and Equity in Education, PISA, OECD Publishing, Paris, https://dx.doi.org/10.1787/9789264266490-en.

OECD (2015), The ABC of Gender Equality in Education: Aptitude, Behaviour, Confidence, PISA, OECD Publishing, Paris, https://dx.doi.org/10.1787/9789264229945-en.

OECD/EU (2017), The Missing Entrepreneurs 2017: Policies for Inclusive Entrepreneurship, OECD Publishing, Paris, https://dx.doi.org/10.1787/9789264283602-en.

Puri, M. and R. Zarutskie (2012), "On the Life Cycle Dynamics of Venture-Capital- and NonVenture-Capital-Financed Firms", The Journal of Finance, http://dx.doi.org/10.1111/j.1540$\underline{6261.2012 .01786 . x}$.

Ragozzino, R. and D. Blevins (2015), "Venture-Backed Firms: How Does Venture Capital Involvement Affect Their Likelihood of Going Public or Being Acquired?", Entrepreneurship Theory and Practice, Vol. 40/5, pp. 991-1016, http://dx.doi.org/10.1111/etap.12154.

Rin, M., T. Hellmann and M. Puri (2013), “A Survey of Venture Capital Research”, in Handbook of the Economics of Finance, Elsevier, http://dx.doi.org/10.1016/b978-0-44453594-8.00008-2.

Schumpeter, J. (1911), The Theory of Economic Development; An Inquiry into Profits, Capital, Credit, Interest, and the Business Cycle, Harvard University Press, http://www.hup.harvard.edu/catalog.php?isbn=9780674879904.

Shane, S. and T. Stuart (2002), "Organizational Endowments and the Performance of University Start-ups", Management Science, Vol. 48/1, pp. 154-170, http://dx.doi.org/10.1287/mnsc.48.1.154.14280.

Song, M. et al. (2008), "Success Factors in New Ventures: A Meta-analysis", Journal of Product Innovation Management, Vol. 25/1, pp. 7-27, https://ris.utwente.nl/ws/files/6458114/success_factors.pdf (accessed on 27 September 2018).

Stephan, P. and A. El-Ganainy (2007), "The entrepreneurial puzzle: explaining the gender gap", The Journal of Technology Transfer, Vol. 32/5, pp. 475-487, http://dx.doi.org/10.1007/s10961-007-9033-3. 


\section{Annex A. Summary statistics for main sample}

\section{Figure A.1. Female-founded start-ups across other countries}

Share of companies with at least one female founder

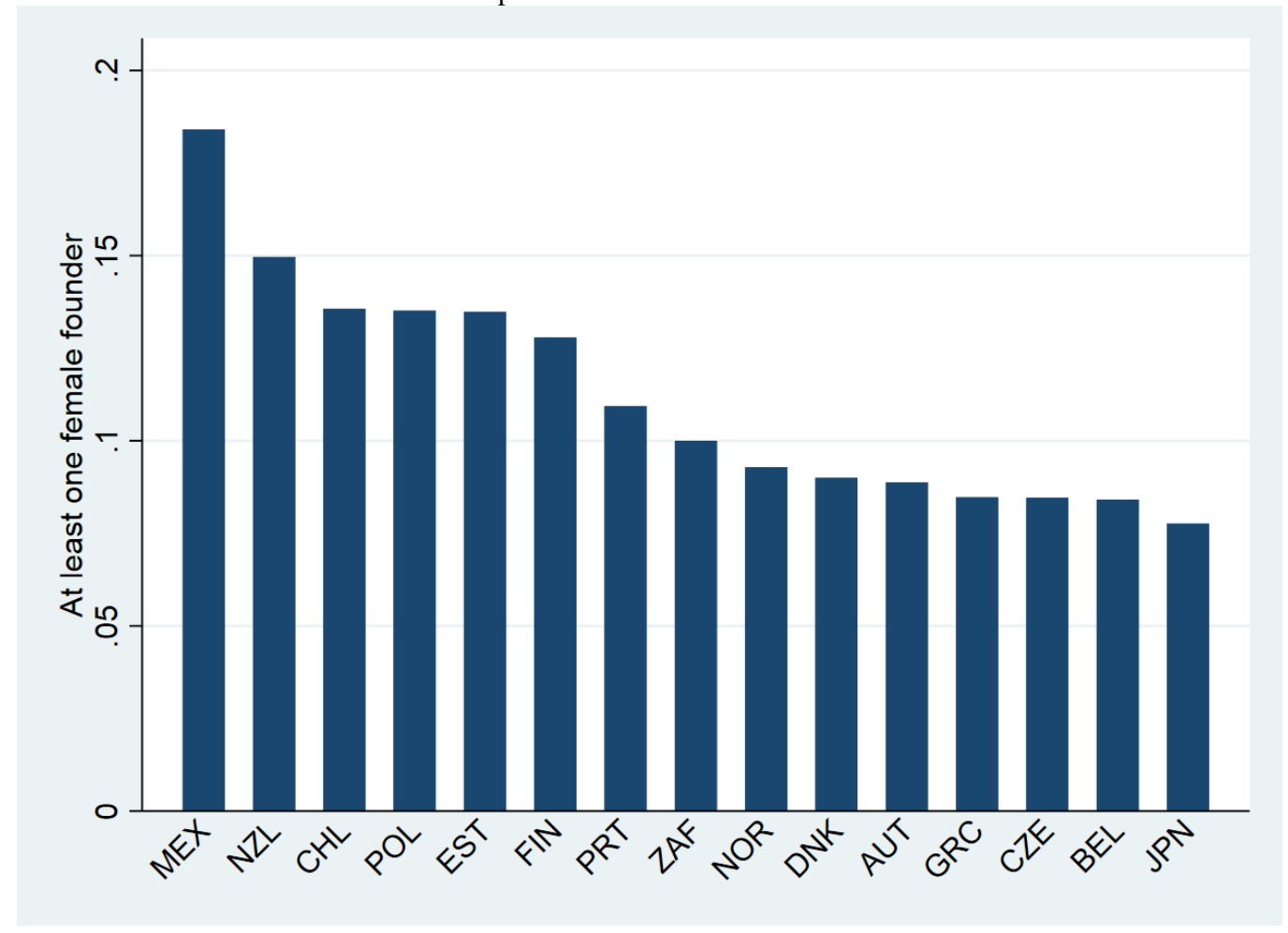

Note: Graph limited to countries counting between 200 and 800 observations in the main database used for analysis. The sample is limited to companies in OECD, Colombia and BRICS countries, founded between 2000 and 2017.

Source: Authors' elaborations on www.crunchbase.com 
Table A.1. Summary statistics of variables I

Company characteristics

\begin{tabular}{lrrrrr}
\hline & Mean & $\begin{array}{c}\text { Standard } \\
\text { deviation }\end{array}$ & Min & Max & \multicolumn{2}{c}{$\begin{array}{c}\text { Number of } \\
\text { observations }\end{array}$} \\
\hline Company has received funding & 0.54 & 0.50 & 0.00 & 1.00 & 70362 \\
Number of funding rounds & 1.16 & 1.62 & 0.00 & 24.00 & 70362 \\
Total funding (top 1\% trimmed, millions & 12.33 & 27.67 & 0.00 & 237.49 & 32110 \\
USD) & 0.13 & 0.33 & 0.00 & 1.00 & 70362 \\
Successful exit & 0.02 & 0.12 & 0.00 & 1.00 & 70362 \\
IPO & 0.11 & 0.32 & 0.00 & 1.00 & 70362 \\
Acquisition & 0.52 & 0.50 & 0.00 & 1.00 & 70358 \\
1 founder & 0.31 & 0.46 & 0.00 & 1.00 & 70358 \\
2 founders & 0.12 & 0.32 & 0.00 & 1.00 & 70358 \\
3 founders & 0.05 & 0.21 & 0.00 & 1.00 & 70358 \\
\hline 4 founders or more & & & \\
\hline
\end{tabular}

Note: The main sample contains data for all OECD countries, Colombia and the BRICS. Total funding amounts exceeding USD 225 millions (99th percentile) are excluded to ensure that analyses are not driven by few companies receiving large deals.

Source: Authors' elaborations on www.crunchbase.com 
Table A.2. Summary statistics of variables II

Founders' characteristics

\begin{tabular}{|c|c|c|c|c|c|}
\hline & Mean & $\begin{array}{l}\text { Standard } \\
\text { deviation }\end{array}$ & Min & Max & $\begin{array}{l}\text { Number of } \\
\text { observations }\end{array}$ \\
\hline \multicolumn{6}{|l|}{ Demographics } \\
\hline At least one founder is a woman dummy & 0.15 & 0.35 & 0.00 & 1.00 & 70362 \\
\hline At least one founder is younger than 20 dummy & 0.18 & 0.38 & 0.00 & 1.00 & 26385 \\
\hline At least one founder is between $20-35$ & 0.69 & 0.46 & 0.00 & 1.00 & 26385 \\
\hline At least one founder is older than 35 dummy & 0.20 & 0.40 & 0.00 & 1.00 & 26385 \\
\hline At least one founder has received a patent & 0.06 & 0.23 & 0.00 & 1.00 & 70362 \\
\hline \multicolumn{6}{|l|}{ Employment variables } \\
\hline \multicolumn{6}{|l|}{$\begin{array}{l}\text { At least one founder has latest experience } \\
\text { as/in... }\end{array}$} \\
\hline CEO & 0.19 & 0.39 & 0.00 & 1.00 & 24838 \\
\hline Leadership & 0.55 & 0.50 & 0.00 & 1.00 & 24838 \\
\hline Academic & 0.16 & 0.37 & 0.00 & 1.00 & 24838 \\
\hline Computer Scientist & 0.27 & 0.44 & 0.00 & 1.00 & 24838 \\
\hline Finance & 0.10 & 0.30 & 0.00 & 1.00 & 24838 \\
\hline Engineer & 0.23 & 0.42 & 0.00 & 1.00 & 24838 \\
\hline Business & 0.39 & 0.49 & 0.00 & 1.00 & 24838 \\
\hline Self-employed & 0.07 & 0.25 & 0.00 & 1.00 & 24838 \\
\hline \multicolumn{6}{|l|}{ Education variables } \\
\hline \multicolumn{6}{|l|}{ At least one founder holds ... } \\
\hline At least one founder holds a PhD dummy & 0.13 & 0.33 & 0.00 & 1.00 & 25471 \\
\hline At least one founder holds an MBA dummy & 0.19 & 0.40 & 0.00 & 1.00 & 25471 \\
\hline At least one founder holds an M.Sc dummy & 0.38 & 0.49 & 0.00 & 1.00 & 25471 \\
\hline At least one founder holds an BSc dummy & 0.83 & 0.37 & 0.00 & 1.00 & 25471 \\
\hline \multicolumn{6}{|l|}{ At least one founder with latest major in ... } \\
\hline IT & 0.22 & 0.41 & 0.00 & 1.00 & 25205 \\
\hline Natural Sciences & 0.07 & 0.25 & 0.00 & 1.00 & 25205 \\
\hline Engineering & 0.15 & 0.36 & 0.00 & 1.00 & 25205 \\
\hline Health & 0.02 & 0.14 & 0.00 & 1.00 & 25205 \\
\hline Social Sciences & 0.10 & 0.30 & 0.00 & 1.00 & 25205 \\
\hline Humanities & 0.07 & 0.25 & 0.00 & 1.00 & 25205 \\
\hline Business \& law & 0.38 & 0.49 & 0.00 & 1.00 & 25205 \\
\hline Education & 0.01 & 0.09 & 0.00 & 1.00 & 25205 \\
\hline Generics & 0.02 & 0.12 & 0.00 & 1.00 & 25205 \\
\hline Services & 0.01 & 0.10 & 0.00 & 1.00 & 25205 \\
\hline
\end{tabular}

Note: The main sample contains data for all OECD countries, Colombia and the BRICS.

Source: Authors' elaborations on www.crunchbase.com 
Table A.3. Summary statistics of main variables by country

\begin{tabular}{|c|c|c|c|c|c|c|c|c|}
\hline Country & $\begin{array}{l}\text { Number of } \\
\text { observations }\end{array}$ & $\begin{array}{l}\text { Share of } \\
\text { start-ups } \\
\text { with only } \\
\text { female } \\
\text { founders }\end{array}$ & $\begin{array}{l}\text { Share of } \\
\text { start-ups } \\
\text { with at least } \\
\text { one female } \\
\text { founder }\end{array}$ & $\begin{array}{l}\text { Share of } \\
\text { start-ups } \\
\text { receiving } \\
\text { VC }\end{array}$ & $\begin{array}{l}\text { Share of } \\
\text { female } \\
\text { founded } \\
\text { start-ups } \\
\text { receiving } \\
\text { VC }\end{array}$ & $\begin{array}{l}\text { Average } \\
\text { funding } \\
\text { received } \\
\text { (millions, } \\
\text { USD) }\end{array}$ & $\begin{array}{c}\text { Average } \\
\text { funding } \\
\text { for } \\
\text { female } \\
\text { founded } \\
\text { start- } \\
\text { ups }\end{array}$ & Most important sectors \\
\hline AUS & 1047 & 0.08 & 0.16 & 0.43 & 0.4 & 6.42 & 2.52 & $\begin{array}{l}\text { Software, internet services, } \\
\text { commerce and shopping }\end{array}$ \\
\hline BRA & 713 & 0.04 & 0.11 & 0.49 & 0.46 & 7.06 & 3.37 & $\begin{array}{l}\text { commerce and shopping, } \\
\text { software, internet services }\end{array}$ \\
\hline CAN & 2527 & 0.05 & 0.13 & 0.47 & 0.46 & 8.51 & 5.69 & $\begin{array}{l}\text { Software, internet services, } \\
\text { media and entertainment }\end{array}$ \\
\hline CHE & 551 & 0.04 & 0.12 & 0.54 & 0.56 & 10.89 & 8.54 & $\begin{array}{l}\text { Software, health care, } \\
\text { internet services }\end{array}$ \\
\hline $\mathrm{CHN}$ & 947 & 0.06 & 0.12 & 0.88 & 0.81 & 27.94 & 29.68 & $\begin{array}{l}\text { Software, commerce and } \\
\text { shopping, internet services }\end{array}$ \\
\hline DEU & 1752 & 0.03 & 0.1 & 0.58 & 0.59 & 11.5 & 13.3 & $\begin{array}{l}\text { Software, internet services, } \\
\text { commerce and shopping }\end{array}$ \\
\hline DNK & 400 & 0.03 & 0.09 & 0.58 & 0.5 & 4.94 & 3.35 & $\begin{array}{l}\text { Software, internet services, } \\
\text { commerce and shopping }\end{array}$ \\
\hline ESP & 1360 & 0.07 & 0.16 & 0.43 & 0.45 & 3.86 & 1.49 & $\begin{array}{l}\text { Software, internet services, } \\
\text { commerce and shopping }\end{array}$ \\
\hline FIN & 391 & 0.04 & 0.13 & 0.58 & 0.46 & 5.51 & 3.05 & $\begin{array}{l}\text { Software, mobile, internet } \\
\text { services }\end{array}$ \\
\hline FRA & 1500 & 0.04 & 0.1 & 0.56 & 0.52 & 8.31 & 5.6 & $\begin{array}{l}\text { Software, internet services } \\
\text { media and entertainment }\end{array}$ \\
\hline GBR & 5258 & 0.06 & 0.15 & 0.54 & 0.54 & 7.36 & 5.86 & $\begin{array}{l}\text { Software, internet services, } \\
\text { media and entertainment }\end{array}$ \\
\hline IND & 4047 & 0.04 & 0.14 & 0.45 & 0.5 & 8.59 & 6.94 & $\begin{array}{l}\text { Software, commerce and } \\
\text { shopping, internet services }\end{array}$ \\
\hline IRL & 544 & 0.07 & 0.14 & 0.6 & 0.63 & 7.82 & 2.03 & $\begin{array}{l}\text { Software, internet services, } \\
\text { media and entertainment }\end{array}$ \\
\hline ISR & 1566 & 0.04 & 0.11 & 0.49 & 0.47 & 12.1 & 11.08 & Software, health care, mobile \\
\hline ITA & 623 & 0.05 & 0.17 & 0.55 & 0.57 & 2.07 & 0.75 & $\begin{array}{l}\text { Software, commerce and } \\
\text { shopping, internet services }\end{array}$ \\
\hline NLD & 877 & 0.03 & 0.09 & 0.49 & 0.5 & 5.88 & 6.56 & $\begin{array}{l}\text { Software, internet services, } \\
\text { media and entertainment }\end{array}$ \\
\hline RUS & 381 & 0.03 & 0.12 & 0.58 & 0.68 & 6.69 & 2.06 & $\begin{array}{l}\text { Software, internet services, } \\
\text { commerce and shopping }\end{array}$ \\
\hline SWE & 556 & 0.04 & 0.1 & 0.58 & 0.56 & 7.4 & 7.22 & $\begin{array}{l}\text { Software, commerce and } \\
\text { shopping, internet services }\end{array}$ \\
\hline TUR & 524 & 0.06 & 0.13 & 0.28 & 0.36 & 2.57 & 4.31 & $\begin{array}{l}\text { Software, internet services, } \\
\text { commerce and shopping }\end{array}$ \\
\hline USA & 41141 & 0.07 & 0.16 & 0.56 & 0.54 & 14.84 & 10.56 & $\begin{array}{l}\text { commerce and shopping, } \\
\text { software, internet services }\end{array}$ \\
\hline REST & 3655 & 0.04 & 0.11 & 0.55 & 0.59 & 4.34 & 2.46 & $\begin{array}{l}\text { Software, internet services, } \\
\text { media and entertainment }\end{array}$ \\
\hline
\end{tabular}

Note: This table shows summary statistics of main variables for top 20 countries in terms of number of start-ups. In columns 6 and 8, female start-ups is understood as start-ups with at least one female founder. Most important sectors in column 9 are in terms of number of start-ups. The groupings used for regional results are the United States (roughly 58\% of the sample), Europe (25\% of the sample, including all EU countries as well as Switzerland, Iceland and Norway) and Asia (11\% of the sample, including China, India, Israel, Japan, Korea and Turkey). Total funding amounts exceeding USD 225 millions (99th percentile) are excluded to ensure that analyses are not driven by few companies receiving large deals.

Source: Authors' elaborations on www.crunchbase.com 


\section{Annex B. Additional regression tables}

\section{Table B.1. Gender gap in probability to get funding}

Results from OLS regressions

\begin{tabular}{|c|c|c|c|c|c|}
\hline & VC dummy & VC dummy & VC dummy & VC dummy & VC dummy \\
\hline At least one founder is a woman dummv & $\begin{array}{r}-0.0481^{* * *} \\
(0.00719)\end{array}$ & $\begin{array}{r}-0.0431^{* * *} \\
(0.00967)\end{array}$ & $\begin{array}{r}-0.0396^{* * *} \\
(0.00949)\end{array}$ & $\begin{array}{r}-0.0348^{* * *} \\
(0.00959)\end{array}$ & $\begin{array}{r}-0.0322^{* * *} \\
(0.00946)\end{array}$ \\
\hline \multirow[t]{2}{*}{2 founders dummy } & $0.133^{\star * *}$ & $0.156^{\star \star *}$ & $0.152^{\star * *}$ & $0.152^{* * *}$ & $0.147^{* * *}$ \\
\hline & $(0.00603)$ & $(0.00816)$ & $(0.00823)$ & $(0.00864)$ & $(0.00866)$ \\
\hline \multirow[t]{2}{*}{3 founders dummy } & $0.218^{\star \star \star}$ & $0.234^{\star * *}$ & $0.228^{\star * *}$ & $0.228^{\star * *}$ & $0.219^{* * *}$ \\
\hline & $(0.0104)$ & $(0.0121)$ & (0.0126) & $(0.0132)$ & $(0.0128)$ \\
\hline \multirow[t]{2}{*}{4 founders or more dummy } & $0.247^{\star \star *}$ & $0.244^{* * *}$ & $0.238^{\star \star *}$ & $0.237^{\star * *}$ & $0.226^{\star * *}$ \\
\hline & $(0.0118)$ & $(0.0150)$ & $(0.0163)$ & $(0.0166)$ & $(0.0161)$ \\
\hline \multirow[t]{2}{*}{ At least one founder is younger than 20 dummy } & & $-0.0460^{\star * *}$ & $-0.0516^{\star * *}$ & $-0.0467^{\star * *}$ & $-0.0416^{* * *}$ \\
\hline & & $(0.00794)$ & $(0.00775)$ & $(0.00813)$ & $(0.00821)$ \\
\hline \multirow[t]{2}{*}{ At least one founder is older than 35 dummy } & & $0.0420^{\star * *}$ & $0.0392^{\star * *}$ & $0.0258^{\star * *}$ & $0.0170^{\star *}$ \\
\hline & & $(0.00857)$ & $(0.00834)$ & $(0.00803)$ & $(0.00825)$ \\
\hline \multirow[t]{2}{*}{ At least one founder holds a PhD dummy } & & $0.0750^{\star * *}$ & $0.0673^{\star \star *}$ & $0.0623^{\star \star \star}$ & $0.0504^{* * *}$ \\
\hline & & $(0.00771)$ & $(0.00845)$ & $(0.00952)$ & $(0.00921)$ \\
\hline \multirow[t]{2}{*}{ At least one founder holds an M.Sc dummy } & & $0.0173^{\star \star}$ & $0.0149^{*}$ & $0.0162^{\star \star}$ & $0.0164^{\star *}$ \\
\hline & & $(0.00769)$ & $(0.00794)$ & $(0.00814)$ & $(0.00795)$ \\
\hline \multirow[t]{2}{*}{ At least one founder holds an MBA dummy } & & $0.0506^{\star * *}$ & $0.0476^{* * *}$ & $0.0451^{* * *}$ & $0.0429^{* * *}$ \\
\hline & & $(0.00677)$ & $(0.00822)$ & $(0.00842)$ & $(0.00855)$ \\
\hline \multirow[t]{2}{*}{ At least one subject: Humanities } & & & $-0.0270^{\star *}$ & $-0.0293^{* *}$ & $-0.0249^{*}$ \\
\hline & & & $(0.0130)$ & $(0.0140)$ & $(0.0138)$ \\
\hline \multirow[t]{2}{*}{ At least one subject: Business \& law } & & & $0.0170^{* *}$ & $0.0146^{*}$ & $0.0190^{\star *}$ \\
\hline & & & $(0.00806)$ & $(0.00823)$ & $(0.00826)$ \\
\hline \multirow[t]{2}{*}{ At least one subject: Engineering } & & & $0.0388^{* * *}$ & $0.0361^{* \star *}$ & $0.0351^{* * *}$ \\
\hline & & & $(0.00746)$ & $(0.00796)$ & $(0.00801)$ \\
\hline \multirow[t]{2}{*}{ At least one subject: Generics } & & & -0.0213 & -0.0178 & -0.0131 \\
\hline & & & $(0.0261)$ & $(0.0260)$ & $(0.0254)$ \\
\hline \multirow[t]{2}{*}{ At least one subject: Health } & & & 0.0188 & 0.0155 & 0.0227 \\
\hline & & & $(0.0201)$ & $(0.0195)$ & $(0.0189)$ \\
\hline \multirow[t]{2}{*}{ At least one subject: IT } & & & 0.00951 & 0.0122 & 0.0115 \\
\hline & & & $(0.00960)$ & $(0.00982)$ & $(0.00997)$ \\
\hline \multirow[t]{2}{*}{ At least one subject: Natural Sciences } & & & $0.0512^{* * *}$ & $0.0509^{\star * *}$ & $0.0498^{* * *}$ \\
\hline & & & $(0.0122)$ & $(0.0118)$ & $(0.0116)$ \\
\hline \multirow[t]{2}{*}{ At least one subject: Services } & & & -0.00211 & 0.00364 & 0.00697 \\
\hline & & & $(0.0313)$ & $(0.0312)$ & (0.0311) \\
\hline \multirow[t]{2}{*}{ At least one subject: Social Sciences } & & & $0.0217^{* *}$ & $0.0214^{\star *}$ & $0.0264^{* * *}$ \\
\hline & & & $(0.00874)$ & $(0.00910)$ & $(0.00928)$ \\
\hline At least one job: Academic & & & & $0.0191^{* *}$ & $0.0172^{*}$ \\
\hline & & & & $(0.00903)$ & $(0.00901)$ \\
\hline At least one job: All business related affairs & & & & $-0.0134^{*}$ & $-0.0132^{*}$ \\
\hline & & & & $(0.00753)$ & $(0.00752)$ \\
\hline At least one job: Computer Scientist & & & & $-0.0258^{* * *}$ & $-0.0272^{\star * *}$ \\
\hline & & & & $(0.00788)$ & $(0.00791)$ \\
\hline At least one job: Finance & & & & $0.0437^{\star \star \star}$ & $0.0444^{* \star *}$ \\
\hline & & & & $(0.0101)$ & $(0.00982)$ \\
\hline At least one job: Engineer & & & & $0.0219^{\star *}$ & $0.0173^{\star \star}$ \\
\hline & & & & $(0.00867)$ & $(0.00877)$ \\
\hline At least one job: Self-employed & & & & -0.000921 & -0.000162 \\
\hline & & & & $(0.0123)$ & $(0.0124)$ \\
\hline At least one job: Leadership & & & & 0.00286 & 0.000659 \\
\hline & & & & $(0.00686)$ & $(0.00681)$ \\
\hline At least one job: CEO & & & & $0.0479^{\star * *}$ & $0.0484^{* * *}$ \\
\hline & & & & $(0.00718)$ & $(0.00720)$ \\
\hline At least one founder has received a patent & & & & & $0.136^{* * *}$ \\
\hline & & & & & $(0.0141)$ \\
\hline Observations & 70,358 & 25,467 & 25,201 & 24,242 & 24,242 \\
\hline R-squared & 0.088 & 0.092 & 0.093 & 0.097 & 0.102 \\
\hline Sector, country, Founding year FE & Yes & Yes & Yes & Yes & Yes \\
\hline
\end{tabular}

Note: Robust clustered standard errors in parentheses. *** $\mathrm{p}<0.01, * * \mathrm{p}<0.05, * \mathrm{p}<0.1$.

Source: Authors' elaborations on www.crunchbase.com 
Table B.2. Gender gap in funding amount

Results from OLS regressions

\begin{tabular}{|c|c|c|c|c|c|}
\hline & Total funding & Total funding & Total funding & Total funding & Total funding \\
\hline \multirow[t]{2}{*}{ At least one founder is a woman dummy } & $-0.412^{* * *}$ & $-0.443^{\star * *}$ & $-0.438^{* * *}$ & $-0.420^{\star * *}$ & $-0.403^{* * *}$ \\
\hline & $(0.0452)$ & $(0.0593)$ & $(0.0570)$ & $(0.0601)$ & $(0.0610)$ \\
\hline \multirow{2}{*}{2 founders dummy } & $0.256^{\star \star \star}$ & $0.380^{\star * *}$ & $0.394^{* \star *}$ & $0.406^{\star \star \star}$ & $0.369^{* * *}$ \\
\hline & $(0.0372)$ & $(0.0568)$ & $(0.0553)$ & $(0.0524)$ & $(0.0560)$ \\
\hline \multirow[t]{2}{*}{3 founders dummy } & $0.514^{\star * \star}$ & $0.665^{\star \star \star}$ & $0.687^{\star \star \star}$ & $0.696^{\star \star \star}$ & $0.637^{* \star *}$ \\
\hline & $(0.0436)$ & $(0.0566)$ & $(0.0575)$ & $(0.0559)$ & (0.0579) \\
\hline \multirow[t]{2}{*}{4 founders or more dummy } & $0.874^{* * *}$ & $1.046^{* \star *}$ & $1.100^{\star \star \star}$ & $1.098^{* * *}$ & $1.026^{\star \star *}$ \\
\hline & $(0.0497)$ & $(0.0639)$ & $(0.0630)$ & $(0.0643)$ & $(0.0651)$ \\
\hline \multirow[t]{2}{*}{ At least one founder is younger than 20 dummy } & & $-0.672^{* * *}$ & $-0.661^{* * *}$ & $-0.629^{* * *}$ & $-0.588^{* * *}$ \\
\hline & & $(0.0428)$ & $(0.0436)$ & $(0.0445)$ & $(0.0439)$ \\
\hline \multirow[t]{2}{*}{ At least one founder is older than 35 dummy } & & $0.424^{* * *}$ & $0.415^{\star \star \star}$ & $0.312^{* \star *}$ & $0.252^{* * *}$ \\
\hline & & $(0.0425)$ & $(0.0420)$ & $(0.0438)$ & $(0.0420)$ \\
\hline \multirow{2}{*}{ At least one founder holds a PhD dummy } & & $0.225^{\star \star \star}$ & $0.216^{\star \star \star}$ & $0.222^{\star \star \star}$ & $0.143^{\star \star *}$ \\
\hline & & $(0.0485)$ & $(0.0466)$ & $(0.0540)$ & $(0.0520)$ \\
\hline \multirow{2}{*}{ At least one founder holds an M.Sc dummy } & & $-0.0867^{\star *}$ & $-0.0738^{*}$ & $-0.0830^{\star *}$ & $-0.0810^{\star *}$ \\
\hline & & $(0.0372)$ & $(0.0381)$ & $(0.0391)$ & $(0.0398)$ \\
\hline \multirow[t]{2}{*}{ At least one founder holds an MBA dummy } & & $0.106^{\star \star}$ & $0.0981^{* *}$ & $0.0822^{*}$ & 0.0668 \\
\hline & & $(0.0448)$ & $(0.0459)$ & $(0.0462)$ & $(0.0447)$ \\
\hline \multirow{2}{*}{ At least one subject: Humanities } & & & $-0.358^{* * *}$ & $-0.344^{* * *}$ & $-0.306^{* * *}$ \\
\hline & & & $(0.0686)$ & $(0.0682)$ & $(0.0691)$ \\
\hline \multirow[t]{2}{*}{ At least one subject: Business \& law } & & & -0.0514 & -0.0753 & -0.0406 \\
\hline & & & $(0.0458)$ & $(0.0472)$ & $(0.0463)$ \\
\hline \multirow[t]{2}{*}{ At least one subject: Engineering } & & & $-0.0850^{*}$ & $-0.111^{* *}$ & $-0.118^{* *}$ \\
\hline & & & $(0.0478)$ & $(0.0472)$ & (0.0471) \\
\hline \multirow[t]{2}{*}{ At least one subject: Generics } & & & $-0.273^{\star \star}$ & $-0.277^{* *}$ & $-0.240^{*}$ \\
\hline & & & $(0.135)$ & $(0.137)$ & $(0.136)$ \\
\hline \multirow[t]{2}{*}{ At least one subject: Health } & & & -0.0808 & -0.0759 & -0.0223 \\
\hline & & & $(0.0953)$ & $(0.0955)$ & (0.0971) \\
\hline \multirow[t]{2}{*}{ At least one subject: IT } & & & $-0.130^{\star *}$ & $-0.132^{\star *}$ & $-0.131^{* *}$ \\
\hline & & & $(0.0570)$ & $(0.0573)$ & (0.0555) \\
\hline \multirow[t]{2}{*}{ At least one subject: Natural Sciences } & & & 0.0467 & 0.0413 & 0.0437 \\
\hline & & & $(0.0668)$ & $(0.0686)$ & $(0.0670)$ \\
\hline \multirow[t]{2}{*}{ At least one subject: Services } & & & $-0.378^{\star *}$ & $-0.356^{* *}$ & $-0.328^{*}$ \\
\hline & & & $(0.169)$ & $(0.170)$ & $(0.171)$ \\
\hline At least one subject: Social Sciences & & & -0.0318 & -0.0569 & -0.0174 \\
\hline & & & $(0.0570)$ & $(0.0590)$ & $(0.0588)$ \\
\hline At least one job: Academic & & & & 0.0117 & -0.00879 \\
\hline & & & & $(0.0393)$ & $(0.0380)$ \\
\hline At least one job: All business related affairs & & & & $-0.111^{* * *}$ & $-0.107^{\star \star \star}$ \\
\hline & & & & $(0.0348)$ & $(0.0337)$ \\
\hline At least one job: Computer Scientist & & & & -0.0217 & -0.0356 \\
\hline & & & & $(0.0471)$ & $(0.0475)$ \\
\hline At least one job: Finance & & & & $0.205^{\star \star *}$ & $0.212^{* * *}$ \\
\hline & & & & $(0.0497)$ & $(0.0506)$ \\
\hline At least one job: Engineer & & & & 0.0574 & 0.0210 \\
\hline & & & & $(0.0552)$ & $(0.0556)$ \\
\hline At least one job: Self-employed & & & & -0.106 & -0.0978 \\
\hline & & & & $(0.0692)$ & $(0.0696)$ \\
\hline At least one job: Leadership & & & & $0.113^{* \star *}$ & $0.0959^{\star \star *}$ \\
\hline & & & & $(0.0351)$ & $(0.0349)$ \\
\hline At least one job: CEO & & & & $0.284^{\star * *}$ & $0.287^{* * *}$ \\
\hline & & & & $(0.0440)$ & $(0.0442)$ \\
\hline At least one founder has received a patent & & & & & $0.812^{* * *}$ \\
\hline & & & & & $(0.0433)$ \\
\hline Observations & 32,078 & 13,598 & 13,466 & 12,975 & $\begin{array}{r}12,975 \\
\end{array}$ \\
\hline R-squared & 0.262 & 0.290 & 0.293 & 0.299 & 0.310 \\
\hline Sector, Country, Founding year FE & Yes & Yes & Yes & Yes & Yes \\
\hline$\%$ difference & -33.771 & -35.787 & -35.479 & -34.301 & -33.197 \\
\hline
\end{tabular}

Note: Robust clustered standard errors in parentheses. $* * * \mathrm{p}<0.01, * * \mathrm{p}<0.05, * \mathrm{p}<0.1$. Total funding amounts exceeding USD 225 millions (99th percentile) are excluded to ensure that analyses are not driven by few companies receiving large deals.

Source: Authors' elaborations on www.crunchbase.com 
Table B.3. Gender gap in likelihood to exit

Results from OLS regressions

\begin{tabular}{|c|c|c|c|c|}
\hline & IPO & IPO & Acquisition & Acquisition \\
\hline At least one founder is a woman dummv & $\begin{array}{r}0.00174 \\
(0.00248)\end{array}$ & $\begin{array}{r}0.00139 \\
(0.00301)\end{array}$ & $\begin{array}{r}-0.0205^{\star * *} \\
(0.00547)\end{array}$ & $\begin{array}{r}-0.0327^{* * *} \\
(0.00843)\end{array}$ \\
\hline \multirow[t]{2}{*}{2 founders dummy } & -0.00144 & -0.00430 & $0.0329^{* * *}$ & $0.0248^{\star * *}$ \\
\hline & $(0.00226)$ & $(0.00326)$ & $(0.00548)$ & $(0.00871)$ \\
\hline \multirow[t]{2}{*}{3 founders dummy } & -0.00331 & $-0.00719^{*}$ & $0.0659^{* * *}$ & $0.0493^{\star * *}$ \\
\hline & $(0.00288)$ & $(0.00377)$ & $(0.00554)$ & $(0.00842)$ \\
\hline \multirow[t]{2}{*}{4 founders or more dummy } & 0.00555 & 0.00457 & $0.0506^{\star * *}$ & $0.0451^{* * *}$ \\
\hline & $(0.00425)$ & $(0.00587)$ & $(0.00904)$ & $(0.0123)$ \\
\hline \multirow[t]{2}{*}{ At least one founder is younger than 20 dummy } & & -0.00229 & & 0.00619 \\
\hline & & $(0.00331)$ & & $(0.00883)$ \\
\hline \multirow{2}{*}{ At least one founder is older than 35 dummy } & & $0.00937^{*}$ & & $-0.0253^{* * *}$ \\
\hline & & $(0.00482)$ & & $(0.00813)$ \\
\hline \multirow[t]{2}{*}{ At least one founder holds a PhD dummy } & & 0.00205 & & $-0.0204^{*}$ \\
\hline & & $(0.00649)$ & & $(0.0116)$ \\
\hline \multirow[t]{2}{*}{ At least one founder holds an M.Sc dummy } & & -0.00252 & & $-0.0108^{*}$ \\
\hline & & $(0.00344)$ & & $(0.00589)$ \\
\hline \multirow[t]{2}{*}{ At least one founder holds an MBA dummy } & & -0.00294 & & 0.0132 \\
\hline & & $(0.00417)$ & & $(0.00942)$ \\
\hline \multirow[t]{2}{*}{ At least one subject: Humanities } & & -0.00306 & & $-0.0336^{* *}$ \\
\hline & & $(0.00419)$ & & $(0.0151)$ \\
\hline \multirow[t]{2}{*}{ At least one subject: Business \& law } & & 0.00359 & & $-0.0152^{*}$ \\
\hline & & $(0.00356)$ & & $(0.00870)$ \\
\hline \multirow[t]{2}{*}{ At least one subject: Engineering } & & -0.00103 & & 0.00791 \\
\hline & & $(0.00416)$ & & $(0.00720)$ \\
\hline \multirow[t]{2}{*}{ At least one subject: Generics } & & -0.00934 & & -0.0263 \\
\hline & & $(0.00665)$ & & $(0.0214)$ \\
\hline \multirow[t]{2}{*}{ At least one subject: Health } & & 0.0134 & & $-0.0364^{* *}$ \\
\hline & & $(0.0115)$ & & $(0.0156)$ \\
\hline \multirow[t]{2}{*}{ At least one subject: IT } & & 0.000247 & & $0.0145^{*}$ \\
\hline & & $(0.00278)$ & & $(0.00804)$ \\
\hline \multirow[t]{2}{*}{ At least one subject: Natural Sciences } & & 0.00847 & & -0.0195 \\
\hline & & $(0.00673)$ & & $(0.0136)$ \\
\hline \multirow[t]{2}{*}{ At least one subject: Services } & & 0.00517 & & -0.0160 \\
\hline & & $(0.00961)$ & & $(0.0202)$ \\
\hline \multirow[t]{2}{*}{ At least one subject: Social Sciences } & & 0.00324 & & 0.00717 \\
\hline & & $(0.00431)$ & & $(0.0108)$ \\
\hline \multirow[t]{2}{*}{ At least one job: Academic } & & -0.00389 & & 0.0114 \\
\hline & & $(0.00471)$ & & $(0.00806)$ \\
\hline At least one job: All business related affairs & & -0.00401 & & 0.00611 \\
\hline & & $(0.00281)$ & & $(0.00662)$ \\
\hline At least one job: Computer Scientist & & 0.00344 & & $0.0259^{* *}$ \\
\hline & & $(0.00283)$ & & $(0.0113)$ \\
\hline At least one job: Finance & & 0.00226 & & -0.00209 \\
\hline & & $(0.00373)$ & & $(0.00976)$ \\
\hline At least one job: Engineer & & $-0.00699^{\star *}$ & & 0.00329 \\
\hline & & $(0.00311)$ & & $(0.00902)$ \\
\hline At least one job: Self-employed & & 0.00506 & & -0.00430 \\
\hline & & $(0.00457)$ & & $(0.0118)$ \\
\hline At least one job: Leadership & & 0.000250 & & -0.00343 \\
\hline & & $(0.00277)$ & & $(0.00678)$ \\
\hline At least one job: CEO & & -0.00313 & & -0.0109 \\
\hline & & $(0.00295)$ & & $(0.00721)$ \\
\hline At least one founder has filed patent application & & $0.0104^{*}$ & & 0.00332 \\
\hline & & $(0.00558)$ & & $(0.0162)$ \\
\hline Observations & 27,310 & 10,888 & 31,522 & 12,785 \\
\hline R-squared & 0.124 & 0.154 & 0.169 & 0.172 \\
\hline Sector, Country, Foundin year FE & Yes & Yes & Yes & Yes \\
\hline
\end{tabular}

Note: Robust clustered standard errors in parentheses. *** $\mathrm{p}<0.01, * * \mathrm{p}<0.05, * \mathrm{p}<0.1$.

Source: Authors' elaborations on www.crunchbase.com 
Table B.4. Heterogeneity across countries - Funding

\begin{tabular}{|c|c|c|c|}
\hline MODEL 1 & $\begin{array}{l}\text { VC dummy } \\
\text { USA }\end{array}$ & $\begin{array}{l}\text { VC dummy } \\
\text { Europe }\end{array}$ & $\begin{array}{l}\text { VC dummy } \\
\text { Asia }\end{array}$ \\
\hline \multirow[t]{2}{*}{$\begin{array}{l}\text { At least one founder is a } \\
\text { woman }\end{array}$} & $-0.0223^{*}$ & $-0.0570^{* * *}$ & 0.00110 \\
\hline & $(0.0132)$ & $(0.0193)$ & $(0.0262)$ \\
\hline Observations & 14,712 & 5,132 & 2,664 \\
\hline R-squared & 0.098 & 0.102 & 0.134 \\
\hline MODEL 2 & $\begin{array}{l}\text { Total funding } \\
\text { USA }\end{array}$ & $\begin{array}{l}\text { Total funding } \\
\text { Europe }\end{array}$ & $\begin{array}{l}\text { Total funding } \\
\text { Asia }\end{array}$ \\
\hline \multirow[t]{2}{*}{$\begin{array}{l}\text { At least one founder is a } \\
\text { woman }\end{array}$} & $-0.441^{\star \star *}$ & $-0.331^{* * *}$ & $-0.382^{*}$ \\
\hline & $(0.0799)$ & $(0.0841)$ & $(0.218)$ \\
\hline Observations & 8,206 & 2,699 & 1,179 \\
\hline R-squared & 0.272 & 0.325 & 0.316 \\
\hline$\%$ difference & -35.661 & -28.17 & -31.774 \\
\hline Controls & $\begin{array}{r}\text { Companies' and } \\
\text { founders' } \\
\text { characteristics }\end{array}$ & $\begin{array}{r}\text { Companies' and founders' } \\
\text { characteristics }\end{array}$ & $\begin{array}{r}\text { Companies' and founders' } \\
\text { characteristics }\end{array}$ \\
\hline Sector FE & Yes & Yes & Yes \\
\hline Year FE & Yes & Yes & Yes \\
\hline Country FE & Yes & Yes & Yes \\
\hline
\end{tabular}

Note: Robust clustered standard errors in parentheses. $* * * \mathrm{p}<0.01, * * \mathrm{p}<0.05, * \mathrm{p}<0.1$. Total funding amounts exceeding USD 225 millions (99th percentile) are excluded to ensure that analyses are not driven by few companies receiving large deals.

Source: Authors' elaborations on www.crunchbase.com

Table B.5. Heterogeneity across countries - Exit

\begin{tabular}{|c|c|c|c|}
\hline MODEL 1 & $\begin{array}{l}\text { IPO } \\
\text { USA }\end{array}$ & $\begin{array}{l}\text { IPO } \\
\text { Europe }\end{array}$ & $\begin{array}{l}\text { IPO } \\
\text { Asia }\end{array}$ \\
\hline $\begin{array}{l}\text { At least one founder is a } \\
\text { woman }\end{array}$ & $\begin{array}{l}0.000349 \\
(0.00371)\end{array}$ & $\begin{array}{r}-0.00866 \\
(0.00589)\end{array}$ & $\begin{array}{r}0.0178^{*} \\
(0.0107)\end{array}$ \\
\hline Observations & 6,583 & 2,446 & 1,053 \\
\hline R-squared & 0.185 & 0.181 & 0.161 \\
\hline MODEL 2 & $\begin{array}{l}\text { Acquisitions } \\
\text { USA }\end{array}$ & $\begin{array}{l}\text { Acquisitions } \\
\text { Europe }\end{array}$ & $\begin{array}{l}\text { Acquisitions } \\
\text { Asia }\end{array}$ \\
\hline $\begin{array}{l}\text { At least one founder is a } \\
\text { woman }\end{array}$ & $-0.0459^{* * *}$ & -0.000911 & -0.00489 \\
\hline & $(0.0102)$ & $(0.0151)$ & $(0.0276)$ \\
\hline Observations & 8,079 & 2,670 & 1,171 \\
\hline R-squared & 0.186 & 0.146 & 0.200 \\
\hline Controls & $\begin{array}{r}\text { Companies' and } \\
\text { founders' } \\
\text { characteristics }\end{array}$ & $\begin{array}{r}\text { Companies' and founders' } \\
\text { characteristics }\end{array}$ & $\begin{array}{r}\text { Companies' and founders' } \\
\text { characteristics }\end{array}$ \\
\hline Funding category FE & Yes & Yes & Yes \\
\hline Sector FE & Yes & Yes & Yes \\
\hline Country FE & Yes & Yes & Yes \\
\hline Founding year FE & Yes & Yes & Yes \\
\hline
\end{tabular}

Note: Robust clustered standard errors in parentheses. ${ }^{* * *} \mathrm{p}<0.01, * * \mathrm{p}<0.05, * \mathrm{p}<0.1$

Source: Authors' elaborations on www.crunchbase.com 
Table B.6. Gender gap in funding for start-ups with male and female founders and start-ups with female founders only

\begin{tabular}{|c|c|c|c|c|c|}
\hline MODEL 1 & $\begin{array}{l}\text { Probability of } \\
\text { funding }\end{array}$ & $\begin{array}{c}\text { Probability of } \\
\text { funding }\end{array}$ & $\begin{array}{l}\text { Probability of } \\
\text { funding }\end{array}$ & $\begin{array}{c}\text { Probability of } \\
\text { funding }\end{array}$ & $\begin{array}{l}\text { Probability of } \\
\text { funding }\end{array}$ \\
\hline \multirow{2}{*}{$\begin{array}{l}\text { Founders are male } \\
\text { and female dummy }\end{array}$} & $-0.0584^{* \star \star}$ & $-0.0529^{* \star *}$ & $-0.0500^{\star \star \star}$ & $-0.0459^{\star \star \star}$ & $-0.0433^{* \star *}$ \\
\hline & $(0.00717)$ & $(0.0106)$ & (0.0104) & $(0.0107)$ & $(0.0106)$ \\
\hline \multirow{2}{*}{$\begin{array}{l}\text { All founders are } \\
\text { female dummy }\end{array}$} & $-0.0346^{\star \star \star}$ & -0.0213 & -0.0160 & -0.00924 & -0.00644 \\
\hline & $(0.0114)$ & $(0.0155)$ & $(0.0152)$ & $(0.0150)$ & $(0.0150)$ \\
\hline Observations & 70,358 & 25,467 & 25,201 & 24,242 & 24,242 \\
\hline R-squared & 0.088 & 0.092 & 0.093 & 0.097 & 0.103 \\
\hline MODEL 2 & $\begin{array}{l}\text { Total funding } \\
\text { (USD, log) }\end{array}$ & $\begin{array}{l}\text { Total funding } \\
\text { (USD, log) }\end{array}$ & $\begin{array}{l}\text { Total funding } \\
\text { (USD, log) }\end{array}$ & $\begin{array}{l}\text { Total funding } \\
\text { (USD, log) }\end{array}$ & $\begin{array}{l}\text { Total funding } \\
\text { (USD, log) }\end{array}$ \\
\hline \multirow{2}{*}{$\begin{array}{l}\text { Founders are male } \\
\text { and female dummy }\end{array}$} & $-0.381^{\star \star \star *}$ & $-0.383^{* \star \star}$ & $-0.382^{\star \star \star}$ & $-0.377^{\star \star *}$ & $-0.364^{* \star *}$ \\
\hline & $(0.0550)$ & $(0.0631)$ & (0.0611) & $(0.0652)$ & $(0.0662)$ \\
\hline \multirow{2}{*}{$\begin{array}{l}\text { All founders are } \\
\text { female dummy }\end{array}$} & $-0.465^{\star \star \star}$ & $-0.617^{\star * *}$ & $-0.601^{* * *}$ & $-0.549^{\star \star *}$ & $-0.520^{* * *}$ \\
\hline & $(0.0707)$ & $(0.101)$ & $(0.0990)$ & $(0.103)$ & $(0.101)$ \\
\hline $\begin{array}{r}\% \text { difference male } \\
\text { and female }\end{array}$ & -31.69 & -31.79 & -31.757 & -31.387 & -30.515 \\
\hline $\begin{array}{r}\% \text { difference only } \\
\text { female }\end{array}$ & -37.187 & -46.036 & -45.148 & -42.231 & -40.559 \\
\hline Controls & $\begin{array}{r}\text { Companies' } \\
\text { characteristics }\end{array}$ & $\begin{array}{r}+ \text { age, } \\
\text { education level }\end{array}$ & $\begin{array}{r}\text { + education } \\
\text { field }\end{array}$ & $\begin{array}{r}+ \text { past } \\
\text { professional } \\
\text { experience }\end{array}$ & + patents \\
\hline
\end{tabular}

Note: Robust clustered standard errors in parentheses. $* * * \mathrm{p}<0.01, * * \mathrm{p}<0.05, * \mathrm{p}<0.1$. Excluded baseline category is the group of start-ups with male founders only. Total funding amounts exceeding USD 225 millions (99th percentile) are excluded to ensure that analyses are not driven by few companies receiving large deals.

Source: Authors' elaborations on www.crunchbase.com

Table B.7. Gender gap in exit for start-ups with male and female founders and start-ups with female founders only

\begin{tabular}{|c|c|c|c|c|}
\hline & IPO & IPO & Acquisition & Acquisition \\
\hline \multirow{2}{*}{$\begin{array}{l}\text { Founders are male } \\
\text { and female dummy }\end{array}$} & $0.00487^{\star}$ & 0.00243 & $-0.0289^{\star * *}$ & $-0.0309^{* * *}$ \\
\hline & $(0.00287)$ & $(0.00301)$ & $(0.00688)$ & $(0.0100)$ \\
\hline \multirow{2}{*}{$\begin{array}{l}\text { All founders are } \\
\text { female dummy }\end{array}$} & -0.00350 & -0.00160 & -0.00596 & $-0.0382^{* * *}$ \\
\hline & $(0.00348)$ & $(0.00529)$ & $(0.00724)$ & $(0.0112)$ \\
\hline Observations & 27,310 & 10,888 & 31,522 & 12,785 \\
\hline R-squared & 0.124 & 0.154 & 0.169 & 0.172 \\
\hline Controls & $\begin{array}{r}\text { Companies' } \\
\text { characteristics }\end{array}$ & $\begin{array}{r}\text { Companies' and } \\
\text { founders' } \\
\text { characteristics }\end{array}$ & $\begin{array}{r}\text { Companies' } \\
\text { characteristics }\end{array}$ & $\begin{array}{r}\text { Companies' and } \\
\text { founders' } \\
\text { characteristics }\end{array}$ \\
\hline
\end{tabular}

Note: Robust clustered standard errors in parentheses. $* * * \mathrm{p}<0.01, * * \mathrm{p}<0.05, * \mathrm{p}<0.1$. Excluded baseline category is the group of start-ups with male founders only.

Source: Authors' elaborations on www.crunchbase.com 


\section{Annex C. Robustness checks}

This subsection discusses results from various robustness exercises. First, results from probit regressions, instead of linear probability models, are reported for the likelihood to receive funding and to experience successful exit. Table C.1 shows that results are unchanged when using a probit model: the gender gap in likelihood to receive funding is statistically different from 0 , and a gender difference in exit can be found for acquisitions but not for IPOs. However, the magnitude of coefficients in Table C.1 cannot be compared with the results presented above, as results from probit regressions do not show directly marginal effects.

Table C.1. Probit results for probability of funding and exit

Type the subtitle here. If you do not need a subtitle, please delete this line.

\begin{tabular}{|c|c|c|c|c|c|c|}
\hline & VC & VC & IPO & IPO & Acquisition & Acquisition \\
\hline \multicolumn{7}{|l|}{ At least one founder is } \\
\hline a woman & $-0.130^{* * *}$ & $-0.0924^{* * *}$ & -0.000223 & -0.0459 & $-0.114^{\star * *}$ & $-0.173^{* * *}$ \\
\hline & $(0.0196)$ & $(0.0273)$ & $(0.0586)$ & $(0.0884)$ & $(0.0308)$ & $(0.0464)$ \\
\hline Observations & 70,356 & 24,242 & 25,763 & 8,605 & 31,454 & 12,678 \\
\hline Controls & $\begin{array}{r}\text { Companies' } \\
\text { characteristics }\end{array}$ & $\begin{array}{l}\text { Companies' } \\
\text { and founders' } \\
\text { characteristics }\end{array}$ & $\begin{array}{r}\text { Companies' } \\
\text { characteristics }\end{array}$ & $\begin{array}{l}\text { Companies' } \\
\text { and founders' } \\
\text { characteristics }\end{array}$ & $\begin{array}{r}\text { Companies' } \\
\text { characteristics }\end{array}$ & $\begin{array}{l}\text { Companies' } \\
\text { and founders' } \\
\text { characteristics }\end{array}$ \\
\hline Funding category FE & No & Yes & Yes & Yes & Yes & Yes \\
\hline Sector FE & Yes & Yes & Yes & Yes & Yes & Yes \\
\hline Country FE & Yes & Yes & Yes & Yes & Yes & Yes \\
\hline Founding year FE & Yes & Yes & Yes & Yes & Yes & Yes \\
\hline
\end{tabular}

Source: Authors' elaborations on www.crunchbase.com

Additionally, unreported results available upon request show that the main effects are not driven by sample size reduction when adding founders' characteristics (age, education level and field, past professional experience) as control variables. This is nevertheless not true for the probability to experience successful exit. Results are also unchanged when regressions are performed at the founder -instead of company- level. Finally, results on successful exit are robust to restricting the sample to companies created before 2010. This ensures that the effect is not driven by the fact that female founded start-ups may take longer to exit. 
Table C.2. Main regressions with country-sector fixed effects

\begin{tabular}{rrrrr}
\hline & VC & $\begin{array}{c}\text { Total funding } \\
\text { (USD, log) }\end{array}$ & Acquisition & IPO \\
\hline $\begin{array}{r}\text { At least one founder is } \\
\text { a woman }\end{array}$ & $-0.0341^{* * *}$ & $-0.420^{* * *}$ & $-0.0296^{* * *}$ & 0.000640 \\
& $(0.00966)$ & $(0.0629)$ & $(0.00889)$ & $(0.00304)$ \\
Observations & 23,915 & 12,657 & 12,472 & 10,573 \\
R-squared & 0.137 & 0.339 & 0.197 & 0.203 \\
Country-sector FE & Yes & Yes & Yes \\
Founding year FE & Yes & Yes & Yes & Yes \\
\% diff & & -34.282 & Company's and \\
fonnders' \\
\end{tabular}

Note: Total funding amounts exceeding USD 225 millions (99th percentile) are excluded to ensure that analyses are not driven by few companies receiving large deals.

Source: Authors' elaborations on www.crunchbase.com 


\title{
Endnotes
}

\begin{abstract}
${ }^{1}$ More precisely, Cruncbase contains information on entities located in 199 countries. However, the number of observations for each country differs widely, with some countries counting only a few companies. As explained later in the text, the sample used for this report is restricted to companies in OECD, Colombia, and the BRICS, countries for which the coverage of Crunchbase appears sufficiently exhaustive.
\end{abstract}

${ }^{2}$ Companies typically list one or several technological category groups in which they operate (the median number is three in the sample used in this report), choosing from a list of 45. Aggregate statistics are based on fractional counts.

${ }^{3}$ Crunchbase contains information on funding deals in general, classified into different types: angel, convertible note, debt financing, equity crowdfunding, grant, non equity assistance, post ipo debt, post ipo equity, private equity, product crowdfunding, secondary market, seed, venture. Angel, seed, and venture capital represent more than $80 \%$ of the number of deals. In the empirical analyses, VC financing means one of the above.

${ }^{4}$ Figure 5 focuses on the top 20 countries in terms of start-up numbers in the main database used for analysis. Figure A.1 in Appendix shows the same statistics for smaller countries in terms of number of observations.

${ }^{5}$ For instance, in the United States women account for nearly half of employed college graduates age 25 and over, but for only about $25 \%$ of employed STEM degree holders and an even smaller share - just about $20 \%$ - of STEM degree holders working in STEM jobs (Beede et al., 2011). The situation in other OECD countries is very similar (OECD, 2015). See http://www.scwist.ca/programs-and-events/make-possible/.

${ }^{6}$ Results are robust to controlling for country-sector fixed effects instead of country and sector fixed effects, see Table C.2 in Appendix.

${ }^{7}$ These results are not driven by a decrease in sample size associated with the inclusion of founders' characteristics.

${ }^{8}$ In order to calculate returns for the initial financiers' investment, we would need information not only on the contract details for the initial financing but also for all intermediate investments in the start-up, as each of those investments may dilute the stake of the initial financier in the company. This makes it even harder to calculate returns on investment for the investors of these start-ups.

${ }^{9}$ A different type of acquisition that is very common in Silicon Valley is acqui-hires (acquisition + hiring). In this case the buyer is not so much interested in the product of business model developed by the start-up, but rather by the founder(s). In this case, the founders are transferred to the acquiring company.

${ }^{10}$ Results are robust to controlling for country-sector fixed effects, see Table C.2 in Appendix.

${ }^{11}$ More specifically, using results from OLS regressions, we compute the predicted outcome of interest for exclusively male-founded companies and those with at least one female founder, with control variables equal to the average value in the sample.

${ }^{12}$ Terjesen and Elam, 2012 at http://www.intracen.org/article/Women-entrepreneurship-A-force-for-growth/ (accessed on 6 March 2019)

${ }^{13}$ https://www.theglobeandmail.com/business/article-report-reveals-staggering-gender-disparity-incanadian-venture-capital/ (accessed on 6 March 2019) 